\title{
Phylogeny and Pathogenicity of Celoporthe Species from Plantation Eucalyptus in Southern China
}

\author{
Wen Wang, QianLi Liu, GuoQing Li, FeiFei Liu, and ShuaiFei Chen, ${ }^{\dagger}$ China Eucalypt Research Centre (CERC), Chinese Academy of \\ Forestry (CAF), ZhanJiang 524022, GuangDong Province, China
}

\begin{abstract}
The family of Cryphonectriaceae (Diaporthales) includes many important tree pathogens, such as those that cause severe cankers on Eucalyptus trees. Recently, stem canker and cracked bark were observed on 8-yearold Eucalyptus grandis $\times$ E. urophylla trees in a plantation in southern China. Fruiting structures typical of Cryphonectriaceae fungi were observed on the surface of the diseased tissues. In this study, the isolated fungi were identified based on DNA sequence analyses and morphological characteristics, and their pathogenicity was tested on three Eucalyptus clones. DNA sequence comparisons of the internal transcribed spacer (ITS) regions (including the intervening 5.8S nrRNA gene), two regions of $\beta$-tubulin $(B T 2 / B T 1)$, and partial translation elongation factor1- $\alpha$ $(T E F-1 \alpha)$, indicated that these isolates represent Celoporthe syzygii and one previously undescribed species. The undescribed species was also morphologically distinct from the other species of Celoporthe. The new species was described and named $C$. cerciana sp. nov. The

results of this study based on the ITS, $B T 2 / B T 1$, and $T E F-1 \alpha$ sequences indicated that more than one haplotype was isolated from the same Eucalyptus tree. The findings of a previous study, whereby $C$. eucalypti was isolated from the same plantation as that of this study, revealed the high species diversity of Celoporthe within a single plantation, which is associated with a single Eucalyptus sp. in southern China. The results further suggested that hybridization may occur between $C$. syzygii and $C$. eucalypti. In addition to the Eucalyptus trees, $C$. syzygii was also isolated from native Melastoma candidum in the same Eucalyptus plantation. The inoculation results showed that these fungi isolated from E. grandis $\times E$. urophylla and $M$. candidum are pathogenic to all three tested $E$. grandis hybrid clones. Significant differences in tolerance were observed between the tested Eucalyptus clones, suggesting that disease-tolerant Eucalyptus genotypes can be selected for disease management.
\end{abstract}

Eucalyptus (Myrtaceae, Myrtales) trees are widely cultivated for commercial purposes, and approximately 20 million ha (Mha) of $E \mathbf{E}$ calyptus plantations exist in the world. The three largest cultivators of Eucalyptus include Brazil, India, and China (Iglesias-Trabad et al. 2009). In China, approximately 4.5 Mha of Eucalyptus plantations have been established to meet the demand for wood products (Xie et al. 2017). The Eucalyptus plantations are mainly distributed in the FuJian, GuangDong, GuangXi, HaiNan, and YunNan Provinces in southern China. The clones of hybrid Eucalyptus urophylla $\times$ E. grandis are most widely cultivated; E. camaldulensis, E. dunnii, E. globulus, E. pellita, E. smithii, and E. tereticornis, and some hybrids of these species have been planted in relatively smaller areas (Xie et al. 2017).

Similar to other countries, the development of Eucalyptus plantations in China is threatened by disease and insect pests (Wingfield et al. 2015; Zhou and Wingfield 2011). Stem canker, shoot and leaf blight, leaf spot caused by fungi, and stem wilt caused by bacteria are considered the most threatening diseases affecting Eucalyptus plantations in China (Cao 1982; Chen et al. 2017; Li et al. 2017; Li et al. 2018; Lombard et al. 2015; Old et al. 2003; Zhou and Wingfield 2011). These diseases have been observed on different genotypes of Eucalyptus, including the widely cultivated $E$. urophylla $\times E$. grandis clones from southern China ( $\mathrm{Li}$ et al. 2017; Li et al. 2018; Lombard et al. 2015; Zhou and Wingfield 2011).

The family Cryphonectriaceae includes many important tree pathogens (Gryzenhout et al. 2009). Well-known pathogens include Cryphonectria parasitica, which causes chestnut (Fagaceae, Fagales) blight (Anagnostakis 1987), and species of Chrysoporthe that cause

${ }^{\dagger}$ Corresponding author: S. Chen; E-mail: shuaifei.chen@gmail.com

Funding: This study was supported by the National Key R\&D Program of China (project number 2016YFD0600505) and the National Natural Science Foundation of China (NSFC) (project numbers 31622019 and 31400546).

Accepted for publication 27 March 2018.

C 2018 The American Phytopathological Society canker and death in Eucalyptus (Chen et al. 2010; Gryzenhout et al. 2009). Several species of Cryphonectriaceae have been isolated from cankered Eucalyptus trees, and pathogenicity tests have indicated that they were indeed pathogenic to Eucalyptus trees. These species include Celoporthe eucalypti (Chen et al. 2011), C. guangdongensis (Chen et al. 2011), C. indonesiensis (Chen et al. 2011), C. syzygii (Chen et al. 2011), Chrysoporthe austroafricana (Gryzenhout et al. 2004, 2009), C. cubensis (Gryzenhout et al. 2004, 2009), C. deuterocubensis (Gryzenhout et al. 2004, 2009; van der Merwe et al. 2010), C. doradensis (Gryzenhout et al. 2005), Cryptometrion aestuescens (Gryzenhout et al. 2010), and Holocryphia eucalypti (Chen et al. 2013, 2016a). Some Cryphonectriaceae species isolated from other Myrtales tree species, but not Eucalyptus, have been found to produce lesions on inoculated Eucalyptus trees. These include Aurapex penicillata (Gryzenhout et al. 2006), Celoporthe dispersa (Nakabonge et al. 2006), C. fontana (Vermeulen et al. 2013), C. woodiana (Vermeulen et al. 2013), Chrysomorbus lagerstroemiae (Chen et al. 2018), Chrysoporthe hodgesiana (Rodas et al. 2005), Corticimorbus sinomyrti (Chen et al. 2016b), Diversimorbus metrosiderotis (Chen et al. 2013, 2016a), H. capensis (Chen et al. 2013, 2016a), H. gleniana (Chen et al. 2013, 2016a), H. mzansi (Chen et al. 2013, 2016a), and Latruncella aurorae (Vermeulen et al. 2011).

In 2016, during the course of disease surveys on plantation Eucalyptus trees in southern China, cankers were observed on the stems of one $E$. grandis $\times E$. urophylla clone, and the fruiting structures of the fungus on the cankered tissue exhibited the typical morphological characteristics of Cryphonectriaceae. Previous research results have shown that the disease symptoms caused by some different genera and species of Cryphonectriaceae are similar, and the overlaps of morphological characteristics among different Cryphonectriaceae fungi were observed, thereby prompting the use of DNA sequence comparisons for the identification of Cryphonectriaceae (Chen et al. 2011, 2013, 2016a,b; Gryzenhout et al. 2009; van der Merwe et al. 2010; Vermeulen et al. 2013). Thus, the aim of this study was to identify the fungi isolated from these cankers based on DNA sequencing and morphological characteristics. Furthermore, this fungus was inoculated on three widely planted $E$. grandis hybrid clones to test its pathogenicity and evaluate the relative susceptibility of different Eucalyptus genotypes. 


\section{Materials and Methods}

Disease symptoms, samples, and fungal isolations. Disease surveys on Eucalyptus plantations in ZhanJiang Region, GuangDong Province in southern China $\left(21^{\circ} 16^{\prime} 00.967^{\prime \prime} \mathrm{N}, 110^{\circ} 05^{\prime} 32.693^{\prime \prime} \mathrm{E}\right)$ were conducted in June 2016. In one Eucalyptus breeding experimental plantation, each of 12 Eucalyptus clones was planted in a single plot. Large cankers with stromata on the bark surface, which often girdled the infected stems, were observed on one 8-year-old E. grandis $\times$ E. urophylla clone (Fig. 1A) but not on the other clones. For the diseased clone, more than $25 \%$ of Eucalyptus trees were infected, the disease symptoms included cankers and cracked bark, the length of these cankers ranged from 30 to $200 \mathrm{~cm}$, and the entire tree exhibited bark cracking (Fig. 1A, B, and C). The stem sections proximal to the cankers were largely dying, and the stems readily broke in the wind (Fig. 1D). Yellow or orange fruiting structures were present on the surface of the infected bark (Fig. 1E), which displayed the typical morphological characteristics of Cryphonectriaceae (Chen et al. 2010; Gryzenhout et al. 2009). The disease had spread across the trees of this particular clone throughout the plantation. The disease symptoms in the current study were similar to those of cankers caused by Chrysoporthe deuterocubensis on Eucalyptus trees reported in China previously (Chen et al. 2010; van der Merwe et al. 2010), except that the sizes of the cankers and cracked bark in this study were larger than that caused by $C$. deuterocubensis. Diseased stem bark pieces bearing fruiting structures were collected and transported to the laboratory for morphological examination and further assessment, with 5 to 15 bark pieces collected from each of the 10 sampled trees. In addition to the Eucalyptus trees, yellow fruiting structures were also observed on the bark of one native Melastoma candidum (synonym: M. septemnervium; Melastomataceae, Myrtales) shrub in the same plot of the $E$. grandis $\times E$. urophylla clone, and the diseased bark pieces were also collected for further study.

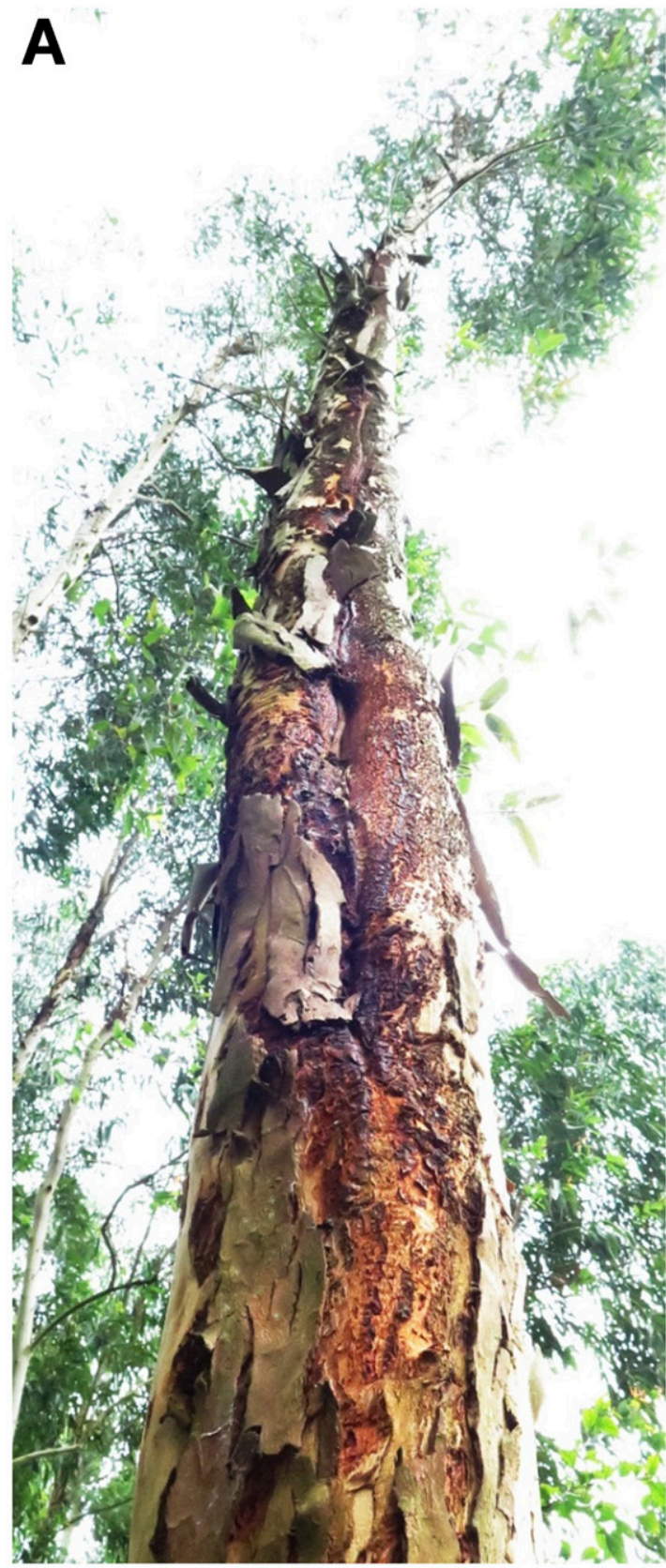

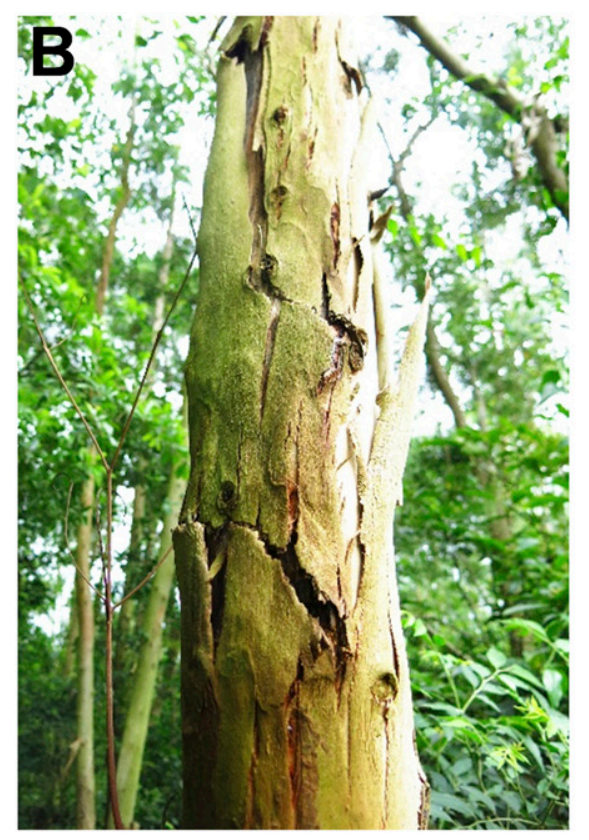

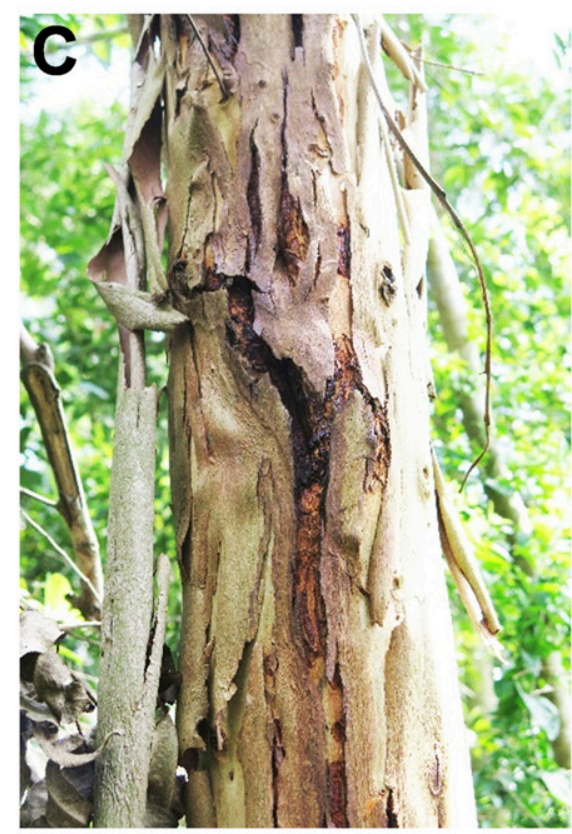

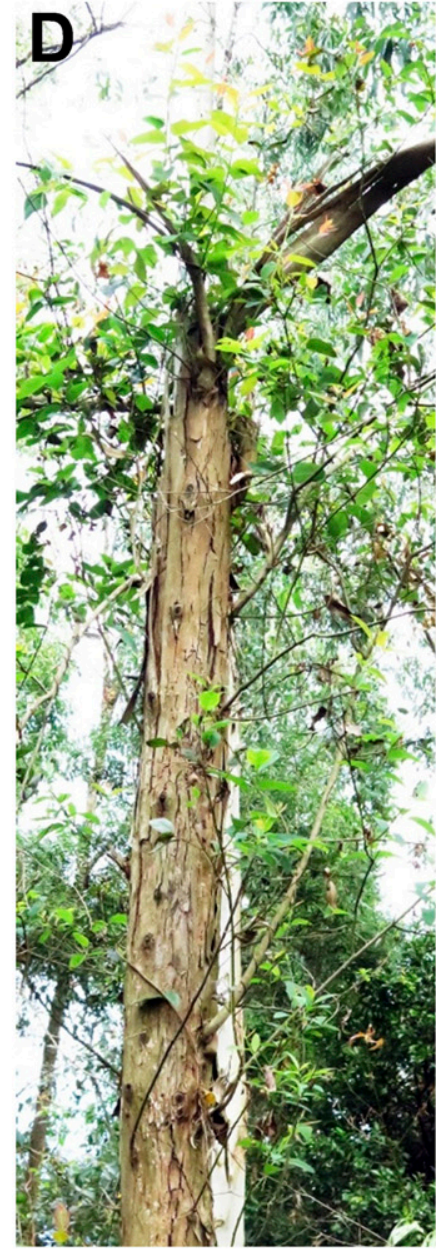

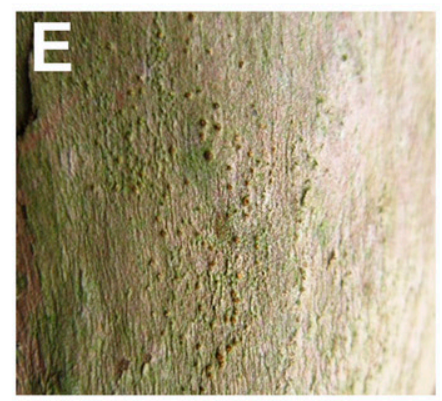

Fig. 1. Disease symptoms on Eucalyptus grandis hybrid associated with infection by Celoporthe spp. A, Cankers on the stem of infected tree. B and C, Cracking of bark on Eucalyptus trees associated with cankers. D, Infected stems readily break in the wind, and epicormics shoots form after stem breakage. E, Fruiting structures of Celoporthe spp. on bark. 
The fruiting structures were incised using a sterile scalpel blade under a dissecting microscope, and the spore masses were transferred to $2 \%$ malt extract agar (MEA) (20 g of malt extract and $20 \mathrm{~g}$ of agar per liter of water) and incubated at room temperature until colonies developed. Single hyphal tips from the colonies were transferred to $2 \%$ MEA to obtain pure cultures. Isolates of Cryphonectriaceae from one $M$. candidum tree were also included in this study. The cultures were deposited in the culture collection of the China Eucalypt Research Centre (CERC), Chinese Academy of Forestry, ZhanJiang, GuangDong Province, China, and representative cultures are being maintained in the China General Microbiological Culture Collection Center (CGMCC), Beijing, China. Isolates linked to the type specimens, and original bark and branch specimens bearing fruiting structures connected to representative isolates, were deposited in the Collection of the Central South Forestry Fungi of China (CSFF), GuangDong Province, China.

DNA extraction, polymerase chain reaction, and sequencing. Isolates collected from different Eucalyptus trees were selected for DNA sequence analysis. The selected isolates were grown on $2 \% \mathrm{MEA}$ at room temperature $\left(25 \pm 2{ }^{\circ} \mathrm{C}\right)$ for 10 days before DNA extraction. The actively growing mycelia for each isolate were directly scraped off from the surface of the MEA medium using a sterile scalpel and transferred into 2-ml Eppendorf tubes. Total genomic DNA was extracted using the "Method 5: Grinding and CTAB" protocol described by van Burik et al. (1998). The extracted DNA was dissolved in $30 \mu \mathrm{l}$ of Tris-EDTA buffer ( $1 \mathrm{M}$ Tris- $\mathrm{HCl}$ and $0.5 \mathrm{M}$ EDTA, $\mathrm{pH}$ 8.0) and then treated with $2.5 \mu \mathrm{l}$ of RNase $(1 \mathrm{mg} / \mathrm{ml})$ for $1 \mathrm{~h}$ at $37^{\circ} \mathrm{C}$ to degrade any RNA present. The resulting DNA concentrations were assessed using a NanoDrop 2000 spectrometer (Thermo Fisher Scientific Inc., Waltham, MA).

Three gene regions, including the internal transcribed spacer (ITS) region that encompasses the 5.8S gene of the ribosomal DNA operon, two segments of the $\beta$-tubulin $(B T 2 / B T 1)$, and a partial segment of the translation elongation factor $1-\alpha(T E F-1 \alpha)$, were amplified and sequenced as described by Chen et al. $(2011,2016 b)$. Nucleotide sequences were edited using MEGA v. 6.0.5 software (Tamura et al. 2013). The sequences obtained in this study were submitted to GenBank (Table 1).

Phylogenetic analyses. To preliminarily identify the isolates sequenced in this study, a standard nucleotide BLAST search using the ITS, BT2/BT1, and TEF-1 $\alpha$ sequences was conducted. The sequences of the ex-type strains of Celoporthe spp. were downloaded from the National Center for Biotechnology Information (https:// www.ncbi.nlm.nih.gov/) and used for the phylogenetic analyses (Table 1).

Phylogenetic analyses were conducted for each of the ITS, BT2/ $B T 1$, and $T E F-1 \alpha$ sequence datasets, as well as for a combined dataset consisting of all the regions. The sequences were aligned using MAFFT online, v. 7 (https://mafft.cbrc.jp/alignment/server/) (Katoh and Standley 2013), implementing the iterative refinement method (FFT-NS-i setting). The alignments were edited manually with MEGA. Alignments and phylogenetic trees for all datasets were deposited in TreeBASE (https://treebase.org). Maximum parsimony (MP) and maximum likelihood (ML) were used to assess branch support in the phylogenetic analyses.

PAUP, v. 4.0 b10 (Swofford 2003), was used for the MP analyses, with gaps treated as the fifth character. Uninformative characters were excluded, and informative characters were unordered and of equal weight with 1,000 random addition replicates. A partition homogeneity test (PHT) in PAUP was conducted to determine whether the datasets of the three regions could be combined. The most parsimonious trees were obtained using the heuristic search option with stepwise addition, tree bisection, and reconstruction branch swapping. MAXTREES was set to 5,000 and zero-length branches were collapsed. A bootstrap analysis (50\% majority rule, 1,000 replicates) was performed to determine statistical support for the internal nodes in the trees. Tree length, consistency index, retention index, and homoplasy index were used to assess the phylogenetic trees (Hillis and Huelsenbeck 1992).
ML analyses were conducted for each dataset using PhyML v. 3.0 (Guindon et al. 2010). The best nucleotide substitution model for each dataset was obtained using the software package jModeltest, v. 1.2.5 (Posada 2008). In PhyML, the maximum number of retained trees was set to 1,000 , and nodal support was determined by nonparametric bootstrapping with 1,000 replicates. For both MP and ML analyses, the phylogenetic trees were viewed in MEGA, and H. capensis (Cryphonectriaceae) (CMW 37331 and CMW 37887) was used as the outgroup taxon for the ITS, BT2/BT1, TEF-1 $\alpha$, and combined datasets.

Morphology. To assess the morphological features of the potential new fungal species, thin branches of three E. grandis hybrid clones (CEPT45: $E$. grandis $\times$ E. urophylla; CEPT46: $E$. urophylla $\times$ E. grandis; and CEPT53: E. urophylla $\times$ E. grandis), which are widely planted in southern China, were used to induce the production of fruiting structures. This method has previously been used in morphological studies of Celoporthe spp. (Chen et al. 2011; Vermeulen et al. 2013) and the species in other Cryphonectriaceae genera (Chen et al. 2016b).

Isolates that were subsequently identified as new species by DNA sequence analysis were grown on plates onto which freshly cut branch sections ( 1 to $2 \mathrm{~cm}$ in diameter and 5 to $6 \mathrm{~cm}$ in length) of three Eucalyptus clones had been added. These branch sections were sterilized, placed onto the surface of $2 \%$ water agar ( $20 \mathrm{~g}$ of agar per liter of water), and incubated at room temperature for 3 weeks until fruiting structures emerged. These isolates originated from different Eucalyptus trees.

The fruiting structures were removed from the specimens under a dissecting microscope, embedded in Leica Biosystems Tissue Freezing Medium (Leica Biosystems Nussloch GmbH, Nussloch, Germany), and sectioned (10 $\mu \mathrm{m}$ thick) using a Microm HM550 Cryostat (Microm International GmbH, Thermo Fisher Scientific, Walldorf, Germany) at $20^{\circ} \mathrm{C}$ to observe the stromata and stromatic tissue (Chen et al. 2018). Conidiophores, conidiogenous cells, and conidia were observed and measured after crushing the fruiting structures on microscope slides in sterilized water. For the holotype specimens, 50 measurements were made for each morphological feature, and 30 measurements per character were performed for the remaining specimens.

Measurements were conducted using an Axio Imager A1 microscope (Carl Zeiss Ltd., Munchen, Germany) and an AxioCam ERc 5S digital camera with Zeiss Axio Vision Rel. 4.8 software (Carl Zeiss Ltd.). The characteristics of the new species in this study were compared with the published genera and species of Cryphonectriaceae (Table 1). The results were presented as (minimum -) (mean standard deviation $)-($ mean + standard deviation) $(-$ maximum $)$.

Isolates identified as new species were used for studying the culture characteristics. A 5-mm plug was removed from each culture after 7 days of growth on 2\% MEA and transferred to the centers of 90mm MEA Petri dishes. The cultures were then incubated under temperatures of 5 to $35^{\circ} \mathrm{C}$ at $5^{\circ} \mathrm{C}$ intervals in the dark, with five replicate plates for each isolate at each temperature condition. Two diameter measurements perpendicular to each other were taken daily for each colony until the fastest growing culture had covered the plate. Averages of the diameter measurements for each temperature were computed with Microsoft Excel 2013 (Microsoft Corporation, Redmond, WA). Colony colors were determined by inoculating the isolates on fresh MEA at $25^{\circ} \mathrm{C}$ in the dark after 7 days of incubation. The color descriptions of the fruiting bodies and colonies followed the color charts of Rayner (1970).

Pathogenicity tests. Isolates from Eucalyptus and $M$. candidum representing different species of Celoporthe identified by DNA sequence comparisons and morphological characteristics were selected for inoculations. Isolates were grown at room temperature $\left(25^{\circ} \mathrm{C} \pm\right.$ $2^{\circ} \mathrm{C}$ ) for 10 days prior to inoculation. One-year-old trees of three widely planted E. grandis hybrid clones (CEPT45, CEPT46, and CEPT53) were used for the pathogenicity tests. The trees were approximately $2 \mathrm{~m}$ tall and $10 \mathrm{~mm}$ in diameter.

For the inoculations, incisions were made on the stems of the $\mathbf{E u}$ calyptus trees at a consistent height (about $300 \mathrm{~mm}$ above the 
seedling medium) to expose the cambium using a cork borer (5 $\mathrm{mm}$ in diameter). Mycelial plugs were taken from the actively growing colonies of each isolate using the same size cork borer, and inserted into the wounds with the mycelia facing the xylem. Inoculated wounds were encased with masking tape to prevent contamination and desiccation.
Each of the 10 selected isolates was inoculated into the stem of 10 trees of each of the three clones. Ten trees of each clone were also inoculated with sterile MEA plugs to serve as controls. The inoculated trees were arranged randomly in the same shadehouse. Trees were inoculated in July 2017 and the results were evaluated after 30 days by measuring the lengths of the lesions (in millimeters) on the cambium.

Table 1. Isolates used for phylogenetic analyses and pathogenicity tests in this study

\begin{tabular}{|c|c|c|c|c|c|c|c|c|}
\hline \multirow{2}{*}{$\begin{array}{l}\text { Identity, isolate } \\
\text { number }\end{array}$} & \multirow[b]{2}{*}{ Host } & \multirow[b]{2}{*}{ Location } & \multirow[b]{2}{*}{ Collector } & \multicolumn{4}{|c|}{ GenBank accession number ${ }^{a}$} & \multirow[b]{2}{*}{ Reference } \\
\hline & & & & ITS & BT1 & $B T 2$ & $T E F-1 \alpha$ & \\
\hline \multicolumn{9}{|l|}{ Celoporthe cerciana } \\
\hline $\begin{array}{l}\text { CERC9125 }^{\mathrm{c}}= \\
\text { CGMCC3.18867 }^{2}\end{array}$ & $\begin{array}{l}\text { Eucalyptus } \\
\text { grandis } \\
\text { hybrid } \\
\text { tree } 1\end{array}$ & $\begin{array}{l}\text { GuangDong, } \\
\text { China }\end{array}$ & S. F. Chen & MH084349 & MH084379 & MH084409 & MH084439 & This study \\
\hline $\begin{array}{l}\text { CERC9126 }^{c}= \\
\text { CGMCC3.18864 }^{2}\end{array}$ & $\begin{array}{l}\text { E. grandis } \\
\text { hybrid tree } 2\end{array}$ & $\begin{array}{l}\text { GuangDong, } \\
\text { China }\end{array}$ & S. F. Chen & MH084350 & MH084380 & MH084410 & MH084440 & This study \\
\hline $\begin{array}{l}\mathrm{CERC9127}^{\mathrm{c}}= \\
\mathrm{CGMCC3.18865}^{2}\end{array}$ & $\begin{array}{l}\text { E. grandis } \\
\text { hybrid tree } 3\end{array}$ & $\begin{array}{l}\text { GuangDong, } \\
\text { China }\end{array}$ & S. F. Chen & MH084351 & MH084381 & MH084411 & MH084441 & This study \\
\hline $\begin{array}{l}\text { CERC9128 }^{\mathrm{c}, \mathrm{d}}= \\
\text { CGMCC3.18866 }\end{array}$ & $\begin{array}{l}\text { E. grandis } \\
\text { hybrid tree } 4\end{array}$ & $\begin{array}{l}\text { GuangDong, } \\
\text { China }\end{array}$ & S. F. Chen & MH084352 & MH084382 & MH084412 & MH084442 & This study \\
\hline \multicolumn{9}{|l|}{ C. dispersa } \\
\hline CMW 9976d & $\begin{array}{l}\text { Syzygium } \\
\text { cordatum }\end{array}$ & South Africa & M. Gryzenhout & DQ267130 & DQ267136 & DQ267142 & HQ730840 & $\begin{array}{l}\text { Nakabonge } \\
\text { et al. 2006; } \\
\text { Chen et al. } \\
2011\end{array}$ \\
\hline CMW 9978 & S. cordatum & South Africa & M. Gryzenhout & AY214316 & DQ267135 & DQ267141 & HQ730841 & $\begin{array}{l}\text { Nakabonge } \\
\text { et al. 2006; } \\
\text { Chen et al. } \\
2011\end{array}$ \\
\hline \multicolumn{9}{|l|}{ C. eucalypti } \\
\hline CMW 26900 & $\begin{array}{l}\text { Eucalyptus } \\
\text { EC48 clone }\end{array}$ & $\begin{array}{l}\text { GuangDong, } \\
\text { China }\end{array}$ & $\begin{array}{l}\text { X. D. Zhou } \\
\text { and S. F. } \\
\text { Chen }\end{array}$ & HQ730836 & HQ730816 & HQ730826 & HQ730849 & $\begin{array}{l}\text { Chen et al. } \\
2011\end{array}$ \\
\hline CMW 26908d & $\begin{array}{l}\text { Eucalyptus } \\
\text { EC48 clone }\end{array}$ & $\begin{array}{l}\text { GuangDong, } \\
\text { China }\end{array}$ & $\begin{array}{l}\text { X. D. Zhou } \\
\text { and S. F. } \\
\text { Chen }\end{array}$ & HQ730837 & HQ730817 & HQ730827 & HQ730850 & $\begin{array}{l}\text { Chen et al. } \\
2011\end{array}$ \\
\hline \multicolumn{9}{|l|}{ C. fontata } \\
\hline CMW 29375 & S. guineense & Zambia & $\begin{array}{l}\text { M. Vermeulen } \\
\text { and J. Roux }\end{array}$ & GU726940 & GU726952 & GU726952 & JQ824073 & $\begin{array}{l}\text { Vermeulen } \\
\text { et al. } 2013\end{array}$ \\
\hline CMW 29376 & S. guineense & Zambia & $\begin{array}{l}\text { M. Vermeulen } \\
\text { and J. Roux }\end{array}$ & GU726941 & GU726953 & GU726953 & JQ824074 & $\begin{array}{l}\text { Vermeulen } \\
\text { et al. } 2013\end{array}$ \\
\hline \multicolumn{9}{|l|}{ C. guangdongensis } \\
\hline CMW 12750d & Eucalyptus sp. & $\begin{array}{l}\text { GuangDong, } \\
\text { China }\end{array}$ & T. I. Burgess & HQ730830 & HQ730810 & HQ730820 & HQ730843 & $\begin{array}{l}\text { Chen et al. } \\
2011\end{array}$ \\
\hline \multicolumn{9}{|l|}{ C. indonesiensis } \\
\hline CMW 10781 & S. aromaticum & Indonesia & $\begin{array}{l}\text { M. J. } \\
\text { Windfield }\end{array}$ & AY084009 & AY084021 & AY084033 & HQ730842 & $\begin{array}{l}\text { Myburg et al. } \\
\text { 2003; Chen } \\
\text { et al. } 2011\end{array}$ \\
\hline \multicolumn{9}{|l|}{ Celoporthe sp. } \\
\hline CERC10436 $^{\mathrm{c}}$ & $\begin{array}{l}\text { E. grandis } \\
\text { hybrid tree } 7\end{array}$ & $\begin{array}{l}\text { GuangDong, } \\
\text { China }\end{array}$ & $\begin{array}{l}\text { S. F. Chen and } \\
\text { W. Wang }\end{array}$ & MH084378 & MH084408 & MH084438 & MH084468 & This study \\
\hline \multicolumn{9}{|l|}{ C. syzygii } \\
\hline CMW 24912 & S. cumini & $\begin{array}{l}\text { GuangDong, } \\
\text { China }\end{array}$ & $\begin{array}{l}\text { M. J. } \\
\text { Windfield } \\
\text { and } \\
\text { X. D. Zhou }\end{array}$ & HQ730833 & HQ730813 & HQ730823 & HQ730846 & $\begin{array}{l}\text { Chen et al. } \\
2011\end{array}$ \\
\hline CMW 34023d & S. cumini & $\begin{array}{l}\text { GuangDong, } \\
\text { China }\end{array}$ & S. F. Chen & HQ730831 & HQ730811 & HQ730821 & HQ730844 & $\begin{array}{l}\text { Chen et al. } \\
2011\end{array}$ \\
\hline CERC10418 & $\begin{array}{l}\text { E. grandis } \\
\text { hybrid tree } 5\end{array}$ & $\begin{array}{l}\text { GuangDong, } \\
\text { China }\end{array}$ & $\begin{array}{l}\text { S. F. Chen and } \\
\text { W. Wang }\end{array}$ & MH084353 & MH084383 & MH084413 & MH084443 & This study \\
\hline CERC10419 & $\begin{array}{l}\text { E. grandis } \\
\text { hybrid tree } 5\end{array}$ & $\begin{array}{l}\text { GuangDong, } \\
\text { China }\end{array}$ & $\begin{array}{l}\text { S. F. Chen and } \\
\text { W. Wang }\end{array}$ & MH084354 & MH084384 & MH084414 & MH084444 & This study \\
\hline & & & & & & & \multicolumn{2}{|c|}{ (Continued on next page) } \\
\hline
\end{tabular}

${ }^{\mathrm{a}}$ ITS $=$ internal transcribed spacer, $B T 2$ and $B T 1=$ two regions of $\beta$-tubulin, and $T E F-1 \alpha=$ translation elongation factor $1-\alpha$. GenBank numbers in bold were sequenced in this study.

${ }^{\mathrm{b}}$ Isolates in bold were obtained in this study. Designation of isolates and culture collections: $\mathrm{CERC}=\mathrm{China}$ Eucalypt Research Centre; $\mathrm{CAF}=\mathrm{Chinese} \mathrm{Academy}$ of Forestry, ZhanJiang, GuangDong, China; CGMCC = China General Microbiological Culture Collection Center, Beijing, China; and CMW = Tree Protection Co-operative Program, Forestry and Agricultural Biotechnology Institute, University of Pretoria, South Africa.

${ }^{\mathrm{c}}$ Isolates used in pathogenicity test.

${ }^{\mathrm{d}}$ Isolates represent ex-type. 
Reisolations were made from the resultant lesions by cutting small pieces of discolored xylem from the edges of the lesions and placing them on $2 \%$ MEA at room temperature. Reisolations of all trees inoculated as controls and from five randomly selected trees per isolate were then conducted. The identities of the reisolated fungi were verified by the fruiting structures and the disease symptoms produced on the bark of inoculated trees, and the culture morphological comparisons with the original fungi were used for the inoculations. The results were analyzed by one-way analysis of variance using SPSS Statistics 20 software (SPSS 2011).

\section{Results}

Fungal isolations. Only asexual fruiting structures with orange stromatic tissues were observed on the canker barks of Eucalyptus trees

Table 1. (Continued from previous page)

\begin{tabular}{|c|c|c|c|c|c|c|c|c|}
\hline \multirow{2}{*}{$\begin{array}{l}\text { Identity, isolate } \\
\text { number }\end{array}$} & \multirow[b]{2}{*}{ Host } & \multirow[b]{2}{*}{ Location } & \multirow[b]{2}{*}{ Collector } & \multicolumn{4}{|c|}{ GenBank accession number ${ }^{a}$} & \multirow[b]{2}{*}{ Reference } \\
\hline & & & & ITS & BT1 & $B T 2$ & $T E F-1 \alpha$ & \\
\hline CERC10420 $^{c}$ & $\begin{array}{l}\text { E. grandis } \\
\text { hybrid tree } 6\end{array}$ & $\begin{array}{l}\text { GuangDong, } \\
\text { China }\end{array}$ & $\begin{array}{l}\text { S. F. Chen and } \\
\text { W. Wang }\end{array}$ & MH084355 & MH084385 & MH084415 & MH084445 & This study \\
\hline CERC10422 $^{\mathrm{c}}$ & $\begin{array}{l}\text { E. grandis } \\
\text { hybrid tree } 6\end{array}$ & $\begin{array}{l}\text { GuangDong, } \\
\text { China }\end{array}$ & $\begin{array}{l}\text { S. F. Chen and } \\
\text { W. Wang }\end{array}$ & MH084356 & MH084386 & MH084416 & MH084446 & This study \\
\hline CERC10423 & $\begin{array}{l}\text { E. grandis } \\
\text { hybrid tree } 6\end{array}$ & $\begin{array}{l}\text { GuangDong, } \\
\text { China }\end{array}$ & $\begin{array}{l}\text { S. F. Chen and } \\
\text { W. Wang }\end{array}$ & MH084357 & MH084387 & MH084417 & MH084447 & This study \\
\hline CERC10424 & $\begin{array}{l}\text { E. grandis } \\
\text { hybrid tree } 6\end{array}$ & $\begin{array}{l}\text { GuangDong, } \\
\text { China }\end{array}$ & $\begin{array}{l}\text { S. F. Chen and } \\
\text { W. Wang }\end{array}$ & MH084358 & MH084388 & MH084418 & MH084448 & This study \\
\hline CERC10425 & $\begin{array}{l}\text { E. grandis } \\
\text { hybrid tree } 6\end{array}$ & $\begin{array}{l}\text { GuangDong, } \\
\text { China }\end{array}$ & $\begin{array}{l}\text { S. F. Chen and } \\
\text { W. Wang }\end{array}$ & MH084359 & MH084389 & MH084419 & MH084449 & This study \\
\hline CERC10426 & $\begin{array}{l}\text { E. grandis } \\
\text { hybrid tree } 6\end{array}$ & $\begin{array}{l}\text { GuangDong, } \\
\text { China }\end{array}$ & $\begin{array}{l}\text { S. F. Chen and } \\
\text { W. Wang }\end{array}$ & MH084360 & MH084390 & MH084420 & MH084450 & This study \\
\hline CERC10427 & $\begin{array}{l}\text { E. grandis } \\
\text { hybrid tree } 6\end{array}$ & $\begin{array}{l}\text { GuangDong, } \\
\text { China }\end{array}$ & $\begin{array}{l}\text { S. F. Chen and } \\
\text { W. Wang }\end{array}$ & MH084361 & MH084391 & MH084421 & MH084451 & This study \\
\hline $\mathrm{CERC10428}^{\mathrm{c}}$ & $\begin{array}{l}\text { E. grandis } \\
\text { hybrid tree } 6\end{array}$ & $\begin{array}{l}\text { GuangDong, } \\
\text { China }\end{array}$ & $\begin{array}{l}\text { S. F. Chen and } \\
\text { W. Wang }\end{array}$ & MH084362 & MH084392 & MH084422 & MH084452 & This study \\
\hline CERC10429 & $\begin{array}{l}\text { E. grandis } \\
\text { hybrid tree } 6\end{array}$ & $\begin{array}{l}\text { GuangDong, } \\
\text { China }\end{array}$ & $\begin{array}{l}\text { S. F. Chen and } \\
\text { W. Wang }\end{array}$ & МH084363 & MH084393 & MH084423 & MH084453 & This study \\
\hline CERC10430 & $\begin{array}{l}\text { E. grandis } \\
\text { hybrid tree } 6\end{array}$ & $\begin{array}{l}\text { GuangDong, } \\
\text { China }\end{array}$ & $\begin{array}{l}\text { S. F. Chen and } \\
\text { W. Wang }\end{array}$ & МH084364 & MH084394 & MH084424 & MH084454 & This study \\
\hline CERC10433 & $\begin{array}{l}\text { E. grandis } \\
\text { hybrid tree } 7\end{array}$ & $\begin{array}{l}\text { GuangDong, } \\
\text { China }\end{array}$ & $\begin{array}{l}\text { S. F. Chen and } \\
\text { W. Wang }\end{array}$ & MH084365 & MH084395 & MH084425 & MH084455 & This study \\
\hline CERC10434 & $\begin{array}{l}\text { E. grandis } \\
\text { hybrid tree } 7\end{array}$ & $\begin{array}{l}\text { GuangDong, } \\
\text { China }\end{array}$ & $\begin{array}{l}\text { S. F. Chen and } \\
\text { W. Wang }\end{array}$ & МH084366 & MH084396 & MH084426 & MH084456 & This study \\
\hline CERC10442 & $\begin{array}{l}\text { E. grandis } \\
\text { hybrid tree } 8\end{array}$ & $\begin{array}{l}\text { GuangDong, } \\
\text { China }\end{array}$ & $\begin{array}{l}\text { S. F. Chen and } \\
\text { W. Wang }\end{array}$ & МH084367 & МH084397 & MH084427 & MH084457 & This study \\
\hline CERC10443 & $\begin{array}{l}\text { E. grandis } \\
\text { hybrid tree } 8\end{array}$ & $\begin{array}{l}\text { GuangDong, } \\
\text { China }\end{array}$ & $\begin{array}{l}\text { S. F. Chen and } \\
\text { W. Wang }\end{array}$ & МH084368 & MH084398 & MH084428 & MH084458 & This study \\
\hline CERC10447 & $\begin{array}{l}\text { E. grandis } \\
\text { hybrid tree } 8\end{array}$ & $\begin{array}{l}\text { GuangDong, } \\
\text { China }\end{array}$ & $\begin{array}{l}\text { S. F. Chen and } \\
\text { W. Wang }\end{array}$ & MH084369 & MH084399 & MH084429 & MH084459 & This study \\
\hline CERC10448 & $\begin{array}{l}\text { E. grandis } \\
\text { hybrid tree } 8\end{array}$ & $\begin{array}{l}\text { GuangDong, } \\
\text { China }\end{array}$ & $\begin{array}{l}\text { S. F. Chen and } \\
\text { W. Wang }\end{array}$ & MH084370 & MH084400 & MH084430 & MH084460 & This study \\
\hline CERC10449 $^{c}$ & $\begin{array}{l}\text { E. grandis } \\
\text { hybrid tree } 9\end{array}$ & $\begin{array}{l}\text { GuangDong, } \\
\text { China }\end{array}$ & $\begin{array}{l}\text { S. F. Chen and } \\
\text { W. Wang }\end{array}$ & MH084371 & MH084401 & MH084431 & MH084461 & This study \\
\hline CERC10450 & $\begin{array}{l}\text { E. grandis } \\
\text { hybrid tree } 9\end{array}$ & $\begin{array}{l}\text { GuangDong, } \\
\text { China }\end{array}$ & $\begin{array}{l}\text { S. F. Chen and } \\
\text { W. Wang }\end{array}$ & MH084372 & MH084402 & MH084432 & MH084462 & This study \\
\hline CERC10451 & $\begin{array}{l}\text { E. grandis } \\
\text { hybrid tree } 9\end{array}$ & $\begin{array}{l}\text { GuangDong, } \\
\text { China }\end{array}$ & $\begin{array}{l}\text { S. F. Chen and } \\
\text { W. Wang }\end{array}$ & MH084373 & MH084403 & MH084433 & MH084463 & This study \\
\hline CERC10452 & $\begin{array}{l}\text { E. grandis } \\
\text { hybrid tree } 9\end{array}$ & $\begin{array}{l}\text { GuangDong, } \\
\text { China }\end{array}$ & $\begin{array}{l}\text { S. F. Chen and } \\
\text { W. Wang }\end{array}$ & MH084374 & MH084404 & MH084434 & MH084464 & This study \\
\hline CERC10453 $^{c}$ & $\begin{array}{l}\text { Melastoma } \\
\quad \text { candidum } \\
\text { tree } 1\end{array}$ & $\begin{array}{l}\text { GuangDong, } \\
\text { China }\end{array}$ & $\begin{array}{l}\text { S. F. Chen and } \\
\text { W. Wang }\end{array}$ & MH084375 & MH084405 & MH084435 & MH084465 & This study \\
\hline CERC10454 & $\begin{array}{l}\text { M. candidum } \\
\text { tree } 1\end{array}$ & $\begin{array}{l}\text { GuangDong, } \\
\text { China }\end{array}$ & $\begin{array}{l}\text { S. F. Chen and } \\
\text { W. Wang }\end{array}$ & МH084376 & MH084406 & MH084436 & MH084466 & This study \\
\hline CERC10455 & $\begin{array}{l}\text { M. candidum } \\
\text { tree } 1\end{array}$ & $\begin{array}{l}\text { GuangDong, } \\
\text { China }\end{array}$ & $\begin{array}{l}\text { S. F. Chen and } \\
\text { W. Wang }\end{array}$ & MH084377 & MH084407 & MH084437 & MH084467 & This study \\
\hline \multicolumn{9}{|l|}{ C. woodiana } \\
\hline CMW 13936 & $\begin{array}{l}\text { Tibouchina } \\
\text { granulosa }\end{array}$ & South Africa & M. Gryzenhout & DQ267131 & DQ267137 & DQ267143 & JQ824071 & $\begin{array}{l}\text { Vermeulen } \\
\text { et al. } 2013\end{array}$ \\
\hline CMW 13937 & T. granulosa & South Africa & M. Gryzenhout & DQ267132 & DQ267138 & DQ267144 & JQ824072 & $\begin{array}{l}\text { Vermeulen } \\
\text { et al. } 2013\end{array}$ \\
\hline \multicolumn{9}{|c|}{ Holocryphia capensis } \\
\hline CMW 37331 & $\begin{array}{c}\text { Metrosideros } \\
\text { angustifolia }\end{array}$ & South Africa & $\begin{array}{l}\text { J. Roux and } \\
\text { S. F. Chen }\end{array}$ & JQ862860 & JQ862901 & JQ862942 & JQ863057 & $\begin{array}{l}\text { Chen et al. } \\
2013\end{array}$ \\
\hline CMW $37887^{d}$ & M. angustifolia & South Africa & $\begin{array}{l}\text { J. Roux, S. F. } \\
\text { Chen and } \\
\text { F. Roets }\end{array}$ & JQ862854 & JQ862895 & JQ862936 & JQ863051 & $\begin{array}{l}\text { Chen et al. } \\
2013\end{array}$ \\
\hline
\end{tabular}


(Fig. 1E). The morphological characteristics of the Cryphonectriaceae fungi isolated from the same bark were similar, although small differences, including culture color, were observed, and their isolates were identified by DNA sequence comparisons. Isolates obtained from the fruiting structures on MEA were white when young and turned yellow or white yellow with age, and the fruiting structures and isolates on MEA exhibited typical morphological characteristics of Cryphonectriaceae. Twenty-seven isolates of Cryphonectriaceae were obtained from 8 of the 10 sampled trees. Each isolate was obtained from each of the sampled bark pieces. Three Cryphonectriaceae isolates were isolated from one $M$. candidum shrub. These 30 isolates were used for further analyses (Table 1).

Phylogenetic analysis. The BLAST results consistently showed that the isolates collected in this study belonged to genus Celoporthe. The 30 isolates obtained in this study were combined into datasets with the ex-type strains of the seven published Celoporthe spp. (Celoporthe dispersa, C. eucalypti, C. fontata, C. guangdongensis, $C$. indonesiensis, $C$. syzygii, and C. woodiana) (Table 1 ). The polymerase chain reactions resulted in amplicons of approximately 640 , $440 / 490$, and $280 \mathrm{bp}$ for the ITS, $B T 2 / B T 1$, and $T E F-1 \alpha$ regions, respectively. For the datasets of the three regions, the PHT generated a value of $P=0.268$, suggesting that the three datasets exhibited no significant conflict and could be combined for further phylogenetic analysis. All sequences obtained for the isolates of Celoporthe in this study were deposited in GenBank (Table 1). The number of taxa and characters in each of the datasets, and a summary of the most important parameters applied in the MP and ML analyses, are presented in Table 2. The four datasets were deposited in TreeBASE (number 22489).

For each of the four datasets, the MP and ML analyses generated trees with generally consistent topologies and phylogenetic relationships among taxa. Among the trees generated by the single gene dataset, the ITS and $B T 2 / B T 1$ trees showed that all 30 isolates obtained in this study grouped into different lineages, and the $T E F-1 \alpha$ trees showed that the 30 isolates were clustered into the same lineage with C. syzygii (Fig. 2A, B, and C).

Four isolates (CERC9125, CERC9126, CERC9127, and CERC9128) formed a novel monophyletic lineage that was distinct from any known Celoporthe sp., and this was supported by high bootstrap values in both the ITS (ML and MP: 93 and 98\%) and BT2/BT1 (ML and MP: 91 and 97\%) trees (Fig. 2A and B). Isolate CERC10436 was grouped into the same lineage with $C$. eucalypti in the ITS trees (Fig. 2A) and clustered with $C$. syzygii in the TEF$1 \alpha$ trees (Fig. 2C) but was not grouped into the same lineage with the ex-type strains of $C$. syzygii or $C$. eucalypti in the BT2/BT1 tree (Fig. 2B). Four isolates (CERC10442, CERC10443, CERC10447, and CERC10448) formed a single independent lineage that was supported

Table 2. Statistics resulting from phylogenetic analyses in this study ${ }^{\mathrm{a}}$

\begin{tabular}{|c|c|c|c|c|}
\hline Variables $^{\mathbf{b}}$ & ITS & BT2/BT1 & $T E F-1 \alpha$ & $\begin{array}{c}\text { ITS }+B T 2 / B T 1 \\
+T E F-1 \alpha\end{array}$ \\
\hline $\begin{array}{l}\text { Number } \\
\text { of taxa }\end{array}$ & 44 & 44 & 44 & 44 \\
\hline $\begin{array}{l}\text { Number of } \\
\text { base pairs }\end{array}$ & 649 & 824 & 282 & 1755 \\
\hline PIC & 113 & 138 & 75 & 326 \\
\hline $\begin{array}{l}\text { Number } \\
\text { of trees }\end{array}$ & 132 & 12 & 3 & 112 \\
\hline Tree length & 146 & 175 & 89 & 430 \\
\hline CI & 0.925 & 0.886 & 0.955 & 0.872 \\
\hline RI & 0.976 & 0.954 & 0.979 & 0.949 \\
\hline $\mathrm{HI}$ & 0.075 & 0.114 & 0.045 & 0.128 \\
\hline Model & TIM2ef $+\mathrm{G}$ & TIM3+G & TPM2uf & $\mathrm{TrN}+\mathrm{G}$ \\
\hline NST & 6 & 6 & 6 & 6 \\
\hline$\gamma$ & 0.610 & 0.141 & $\ldots$ & 0.234 \\
\hline
\end{tabular}

by high bootstrap values in the ITS trees (ML and MP: 91 and 98\%) (Fig. 2A) but this was not observed in the BT2/BT1 trees (Fig. 2B).

Among the ITS and BT2/BT1 trees, the rest of the Celoporthe isolates obtained in this study were grouped into the same lineage with C. syzygii or formed single independent clades but the bootstrap values within the $C$. syzygii clade were not significant (Fig. 2A and B), which suggests that these differences reflect intraspecific rather than interspecific variations. The combined ITS, BT2/BT1, and $T E F-1 \alpha$ trees (Fig. 2D) indicated that the isolates CERC9125, CERC9126, CERC9127, and CERC9128 are putative novel species (bootstrap values of the combined dataset, ML and MP: 100 and 100\%). Isolate CERC10436 may present a hybrid of C. eucalypti and C. syzygii. The remaining 25 isolates, including three from $M$. candidum, were identified as $C$. syzygii.

The results of single-nucleotide polymorphism (SNP) analyses supported the observation that the new Celoporthe spp. (isolates CERC9125, CERC9126, CERC9127, and CERC9128) identified in this study differ from those of other phylogenetically closed related Celoporthe spp. (C. eucalypti, C. guangdongensis, C. indonesiensis, and $C$. syzygii). Comparisons of the three gene regions showed that the total number of SNP differences among the five species for all three gene regions combined varied between 19 and 38 unique SNP (Table 3). No nucleotide differences could be detected in the three gene regions for isolates CERC9125, CERC9126, CERC9127, and CERC9128. The SNP analyses revealed intraspecies variations among the $25 \mathrm{C}$. syzygii isolates identified in this study; 1 to 9 nucleotide differences were observed among the eight haplotypes that were detected within the three gene regions (Table 4). The SNP analyses of C. eucalypti, $C$. syzygii, and isolate CERC10436 showed no differences between $C$. eucalypti and isolate CERC10436 for the ITS region, as well as $C$. syzygii and isolate CERC10436 for the TEF-1 $\alpha$ gene region (Table 5). Isolate CERC10436 shared the same nucleotide with either $C$. eucalypti or $C$. syzygii for the $B T 2 / B T 1$ region in some sites (Table 5). These results supported the idea that CERC10436 could be a hybrid of C. eucalypti and C. syzygii.

Morphology and taxonomy. Asexual fruiting structures but no sexual structures were observed on natural diseased Eucalyptus bark collected from the plantation. The conidiomata were superficial to slightly immersed, orange when young, fuscous black when mature, pulvinate with or without short attenuated necks, with paraphyses present; conidia hyaline, nonseptate and oblong to cylindrical. The cultures were fluffy with an uneven margin, white when young, turning yellow white, and pale luteous to luteous after a few days. The asexual structure and culture characteristics of these fungi were typical of species of Celoporthe.

Asexual fruiting structures of the four isolates (CERC9125, CERC9126, CERC9127, and CERC9128) were produced on the incised Eucalyptus branches. No significant variations were observed on the branches of three Eucalyptus clones between the fruiting structures of these isolates and they were morphologically similar to other Celoporthe spp. (Chen et al. 2011; Nakabonge et al. 2006; Vermeulen et al. 2013). Morphological and growth differences were also observed among the structures produced in this study and other described Celoporthe spp., including the presence of conidiomatal necks, the length of the paraphyses, and the optimal growth temperatures (Chen et al. 2011; Nakabonge et al. 2006; Vermeulen et al. 2013). Therefore, the four isolates from the E. grandis $\times$ E. urophylla clone clearly represent one previously undescribed species of Celoporthe. The species is described as follows:

Celoporthe cerciana W. Wang, Q.L. Liu \& S.F. Chen, sp. nov. MycoBank MB824654 (Fig. 3).

Etymology. Name refers to CERC, a research institution that is pioneering the study of tree diseases caused by Celoporthe spp. in China.

Stromata. No ascostromata were observed on the Eucalyptus bark collected from the plantations or on inoculated Eucalyptus branch tissue. The conidiomata on the inoculated Eucalyptus branch tissue were superficial to slightly immersed, pulvinate, globose to pyriform with necks, orange to umber when young, fuscous black when mature. Stromatic tissue prosenchymatous. Stromatic conidiomatal base 

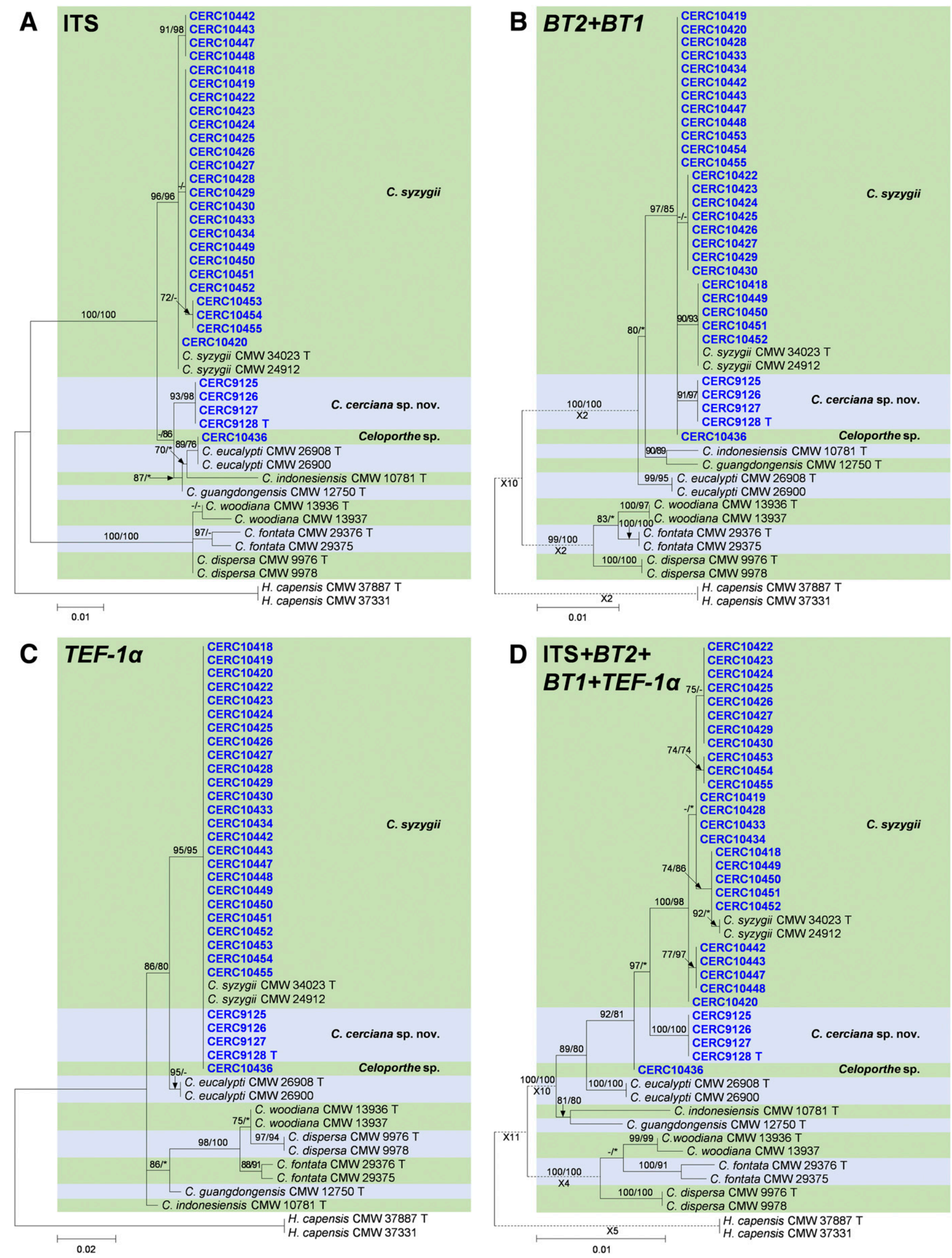

Fig. 2. Phylogenetic trees based on maximum likelihood (ML) analyses for species in Celoporthe. A, Internal transcribed spacer (ITS) region; B, two regions of $\beta$-tubulin (BT2/BT1); C, translation elongation factor1- $\alpha$ (TEF-1 $\alpha)$ gene region; D, combination of ITS, BT2/BT1, and TEF-1 $\alpha$ regions. Isolates in bold were isolated in this study. Bootstrap support values $\geq 70 \%$ for ML and maximum parsimony (MP) are presented above branches as follows: ML/MP, bootstrap support values $<70 \%$ are marked with "-" and absent isolates ( $<50 \%)$ are marked with "*". Isolates representing ex-type sequences are marked with "T". Two isolates of Holocryphia capensis (CM10W37331 and CMW37887) represent the outgroups. 
was 81-361 $\mu \mathrm{m}$ (average $179 \mu \mathrm{m}$ ) high above the level of the bark and 71-381 $\mu \mathrm{m}$ (average $195 \mu \mathrm{m}$ ) wide (Fig. 3A). Conidiomatal necks. Umber to black, 161-595 $\mu \mathrm{m}$ (average $314 \mu \mathrm{m}$ ) long (Fig. 3B). Conidiomatal locules. Unilocular, occasionally multilocular, 43-353 $\mu \mathrm{m}$ (average $204 \mu \mathrm{m}$ ) diameter (Fig. 3C). Conidiophores. Hyaline, branched irregularly at the base or above into cylindrical cells, with or without separating septa, (5.9-)13.4-15(-31.7) $\mu \mathrm{m}$ (average $14.2 \mu \mathrm{m})$ long, $(0.8-) 1.6-1.8(-2.7) \mu \mathrm{m}$ (average $1.7 \mathrm{um}$ ) wide (Fig. 3F and G). Conidiogenous cell. Phialidic, cylindrical, with or without attenuated apices, (0.5-)1.1(-1.6) um (average $1.1 \mathrm{um}$ ) wide (Fig. 3F and G). Paraphyses or cylindrical sterile cells. Occur among conidiophores, up to $88 \mu \mathrm{m}$ (average $44 \mu \mathrm{m}$ ) long (Fig. 3E). Conidia. Hyaline, nonseptate, oblong to cylindrical, occasionally allantoid, extend through an opening at the stromatal surface as orange droplets, $(2.8-) 3.6-3.7(-4.8) \times(1.1-) 1.5(-1.9) \mu \mathrm{m}$ (average $3.6 \times 1.5 \mu \mathrm{m})($ Fig. $3 \mathrm{H})$.

Culture characteristics. Colonies on MEA fluffy with an uneven margin, white when young, turning pale luteous to luteous after 10 days. Colony reverse yellow to yellow-white. Optimal growth temperature $25^{\circ} \mathrm{C}$, reaching the edge of the 90 -mm plates after 7 days.
No growth at 5,10 , and $35^{\circ} \mathrm{C}$. After 7 days, colonies at $15,20,25$, and $30^{\circ} \mathrm{C}$ reached $14.7,39.4,77.6$, and $75.9 \mathrm{~mm}$, respectively.

Substrate.

Bark of E.grandis $\times$ E.urophylla clone.

Distribution. GuangDong Province, China.

Specimens examined. China, GuangDong Province, ZhanJiang Region, SuiXi County, LingBei Town (GPS $21^{\circ} 16^{\prime} 02.8^{\prime \prime} \mathrm{N}$, $\left.110^{\circ} 05^{\prime} 31.3^{\prime \prime} \mathrm{E}\right)$, from $E$. grandis hybrid clone bark collected in a plantation, 18 June 2016, ShuaiFei Chen, (HOLOTYPE CSFF2039, isolate CERC9128 artificial inoculation on E. urophylla $\times$ E. grandis clone CEPT53 branch tissue on 4 June 2017, Wen Wang; ex-type culture CERC9128 = CGMCC3.18866).

Other specimens examined. China, GuangDong Province, ZhanJiang Region, SuiXi County, LingBei Town (GPS 21 ${ }^{\circ} 16^{\prime} 00.967^{\prime \prime} \mathrm{N}, 110^{\circ} 05^{\prime}$ $\left.32.693^{\prime \prime} \mathrm{E}\right)$, from $E$. grandis hybrid clone bark collected in a plantation, 18 June 2016, ShuaiFei Chen, (CSFF2040, isolate CERC9125 artificial inoculation on E. urophylla $\times$ E. grandis clone CEPT53 branch tissue on 4 June 2017, Wen Wang, culture CERC9125 = CGMCC3.18867; CSFF2041, isolate CERC9126 artificial inoculation

Table 3. Single-nucleotide polymorphism comparisons internal transcribed spacer (ITS), two regions of $\beta$-tubulin (BT2/BT1), and translation elongation factor1- $\alpha(T E F-1 \alpha)$ gene regions between Celoporthe cerciana and the phylogenetically closest related species

\begin{tabular}{|c|c|c|c|c|c|c|c|c|c|c|c|c|c|c|c|c|c|c|c|c|c|c|c|c|c|c|c|c|c|}
\hline \multirow{2}{*}{\multicolumn{4}{|c|}{ Species, isolate number ${ }^{b}$}} & \multicolumn{26}{|c|}{ ITS $^{\mathbf{a}}$} \\
\hline & & & & 61 & 69 & 8 & 0 & 38 & 120 & 122 & 124 & & 125 & 126 & 133 & & 134 & 138 & & 141 & 159 & 17 & 73 & 210 & 212 & 22 & & 222 & 228 \\
\hline \multicolumn{4}{|c|}{ C. cerciana CERC9125 } & $\mathrm{C}$ & $\mathbf{T}$ & C & C & $\mathrm{C}$ & G & $\mathrm{T}$ & - & & - & - & $\mathrm{C}$ & & $\mathrm{T}$ & $\mathrm{C}$ & & G & - & $\mathrm{C}$ & S & $\mathrm{C}$ & $\mathrm{C}$ & - & & - & $\mathrm{C}$ \\
\hline \multicolumn{4}{|c|}{ C. cerciana CERC9126 } & $\mathrm{C}$ & $\mathbf{T}$ & $\mathrm{C}$ & $\mathrm{C}$ & $\mathrm{C}$ & $\mathbf{G}$ & $\mathrm{T}$ & - & & - & - & $\mathrm{C}$ & & $\mathrm{T}$ & $\mathrm{C}$ & & G & - & $\mathrm{C}$ & G & $\mathrm{C}$ & $\mathrm{C}$ & - & & - & $\mathrm{C}$ \\
\hline \multicolumn{4}{|c|}{ C. cerciana CERC 9127} & $\mathrm{C}$ & $\mathbf{T}$ & $\mathrm{C}$ & C & $\mathrm{C}$ & $\mathbf{G}$ & $\mathrm{T}$ & - & & - & - & $\mathrm{C}$ & & $\mathrm{T}$ & $\mathrm{C}$ & & $\mathrm{G}$ & - & $\mathrm{C}$ & G & $\mathrm{C}$ & $\mathrm{C}$ & - & & - & $\mathrm{C}$ \\
\hline \multicolumn{4}{|c|}{ C. cerciana CERC9128 } & $\mathrm{C}$ & $\mathbf{T}$ & $\mathrm{C}$ & $\mathrm{C}$ & $\mathrm{C}$ & $\mathbf{G}$ & $\mathrm{T}$ & - & & - & - & $\mathrm{C}$ & & $\mathrm{T}$ & $\mathrm{C}$ & & G & - & $\mathrm{C}$ & G & $\mathrm{C}$ & $\mathrm{C}$ & - & & - & $\mathrm{C}$ \\
\hline \multicolumn{4}{|c|}{ C. eucalypti CMW 26900} & $\mathrm{C}$ & - & C & $\mathrm{C}$ & $\mathrm{C}$ & A & $\mathrm{T}$ & - & & - & - & $\mathrm{C}$ & & $\mathrm{T}$ & $\mathrm{C}$ & & G & - & C & S & $\mathrm{C}$ & $\mathrm{C}$ & - & & $A$ & $\mathrm{C}$ \\
\hline \multicolumn{4}{|c|}{ C. eucalypti CMW 26908} & $\mathrm{C}$ & - & C & $\mathrm{C}$ & $\mathrm{C}$ & A & $\mathrm{T}$ & - & & - & - & $\mathrm{C}$ & & $\mathrm{T}$ & $\mathrm{C}$ & & $\mathrm{G}$ & - & $\mathrm{C}$ & G & $\mathrm{C}$ & $\mathrm{C}$ & - & & $A$ & $\mathrm{C}$ \\
\hline \multicolumn{4}{|c|}{ C. syzygii CMW 24912} & $\mathrm{C}$ & - & C & C & $\mathrm{C}$ & A & $\mathrm{T}$ & - & & - & - & $\mathbf{T}$ & & C & $\mathbf{T}$ & & C & $C$ & $-*$ & & $\mathrm{C}$ & $\mathrm{C}$ & - & & - & $\mathrm{C}$ \\
\hline \multicolumn{4}{|c|}{ C. syzygii CMW $\mathbf{3 4 0 2 3}$} & $\mathrm{C}$ & - & C & C & $\mathrm{C}$ & A & $\mathrm{T}$ & - & & - & - & $\mathbf{T}$ & & C & $\mathbf{T}$ & & C & $C$ & $-*$ & $*$ & $\mathrm{C}$ & $\mathrm{C}$ & - & & - & $\mathrm{C}$ \\
\hline \multirow{2}{*}{\multicolumn{4}{|c|}{$\begin{array}{l}\text { C. guangdongensis CMW } 12750 \\
\text { C. indonesiensis CMW } 10781\end{array}$}} & $\mathrm{C}$ & - & C & C & $\mathrm{C}$ & A & $\mathrm{T}$ & - & & - & - & $\mathrm{C}$ & & $\mathrm{T}$ & $\mathrm{C}$ & & G & $C$ & $\mathrm{C}$ & $\mathrm{G}$ & $\mathrm{C}$ & $\mathrm{C}$ & $\mathbf{A}$ & & $A$ & $\mathrm{C}$ \\
\hline & & & & $\mathbf{A}$ & - & $\mathbf{T}$ & $\Gamma$ & $\mathbf{T}$ & A & $\mathbf{A}$ & $\mathbf{T}$ & & $\mathbf{A}$ & $\mathbf{T}$ & $\mathrm{C}$ & & $\mathrm{T}$ & $\mathrm{C}$ & & G & - & $\mathrm{C}$ & G & $\mathbf{A}$ & $\mathbf{T}$ & - & & - & $\mathbf{A}$ \\
\hline & \multicolumn{15}{|c|}{ ITS } & \multicolumn{11}{|c|}{$B T(B T 2)$} \\
\hline \multicolumn{4}{|c|}{ Species, isolate number } & 247 & 24 & & 252 & 253 & 340 & \multicolumn{2}{|c|}{524} & 576 & 577 & 583 & & 584 & 58 & & 24 & 215 & 22 & & 223 & 224 & 234 & 23 & & 277 & 322 \\
\hline$\overline{\text { C. cerciana CERC }}$ & 9125 & & & $\mathbf{A}$ & C & & - & $\mathrm{A}$ & $\mathrm{A}$ & $T$ & & - & - & $\mathrm{C}$ & & $\mathrm{C}$ & $\mathrm{T}$ & & $\mathrm{C}$ & $\mathrm{C}$ & - & & - & $\mathrm{C}$ & $\mathrm{C}$ & $\mathrm{C}$ & & $\mathrm{C}$ & $A$ \\
\hline C. cerciana CERC & 9126 & & & $\mathbf{A}$ & C & & - & A & A & $T$ & & - & - & $\mathrm{C}$ & & $\mathrm{C}$ & $\mathrm{T}$ & & $\mathrm{C}$ & $\mathrm{C}$ & - & & - & $\mathrm{C}$ & $\mathrm{C}$ & C & & $\mathrm{C}$ & $A$ \\
\hline C. cerciana CERC & 9127 & & & $\mathbf{A}$ & C & & - & A & A & $T$ & & - & - & $\mathrm{C}$ & & $\mathrm{C}$ & $\mathrm{T}$ & & $\mathrm{C}$ & $\mathrm{C}$ & - & & - & $\mathrm{C}$ & $\mathrm{C}$ & C & & $\mathrm{C}$ & $A$ \\
\hline C. cerciana CERC & 9128 & & & $\mathbf{A}$ & C & & - & A & A & $T$ & & - & - & $\mathrm{C}$ & & $\mathrm{C}$ & $\mathrm{T}$ & & $\mathrm{C}$ & $\mathrm{C}$ & - & & - & $\mathrm{C}$ & $\mathrm{C}$ & C & & $\mathrm{C}$ & $A$ \\
\hline C. eucalypti CMW & 2690 & & & $\mathrm{~T}$ & A & & - & $-*$ & A & - & & - & $C$ & $T$ & & A & $\mathrm{T}$ & & $\mathbf{T}$ & $\mathrm{C}$ & - & & $C$ & $\mathrm{C}$ & $\mathbf{T}$ & $\mathrm{C}$ & & $\mathrm{C}$ & $\mathrm{C}$ \\
\hline C. eucalypti CMW & 269 & & & $\mathrm{~T}$ & A & & - & $-*$ & A & - & & - & $C$ & $T$ & & $\mathrm{~A}$ & $\mathrm{~T}$ & & $\mathbf{T}$ & $\mathrm{C}$ & - & & $C$ & $\mathrm{C}$ & $\mathbf{T}$ & C & & $\mathrm{C}$ & $\mathrm{C}$ \\
\hline C. syzygii CMW 2 & 4912 & & & $\mathrm{~T}$ & A & & - & A & A & - & & - & - & $\mathrm{C}$ & & $\mathrm{C}$ & $A$ & & $\mathrm{C}$ & $\mathrm{C}$ & $\mathbf{A}$ & & $C$ & $\mathrm{C}$ & $\mathrm{C}$ & G & & $\mathrm{C}$ & $A$ \\
\hline C. syzygii CMW 3 & 4023 & & & $\mathrm{~T}$ & A & & - & A & A & - & & - & - & $\mathrm{C}$ & & $\mathrm{C}$ & $A$ & & $\mathrm{C}$ & $\mathrm{C}$ & $\mathbf{A}$ & & $C$ & $\mathrm{C}$ & $\mathrm{C}$ & G & & $\mathrm{C}$ & $A$ \\
\hline C. guangdongensis & $\mathbf{C M}$ & {$[\mathbf{W} 1$} & 2750 & $\mathrm{~T}$ & A & & - & $-*$ & A & $T$ & & C & $C$ & $\mathrm{C}$ & & $T$ & $\mathrm{~T}$ & & $\mathrm{C}$ & $\mathrm{C}$ & - & & - & -** & $\mathrm{C}$ & C & & $G$ & $\mathrm{C}$ \\
\hline C. indonesiensis $\mathbf{C}$ & MW & 1078 & & $\mathrm{~T}$ & A & & $\mathbf{A}$ & A & $\mathbf{T}$ & - & & - & - & N/A & & N/A & $\mathrm{N} / \mathrm{A}$ & & $\mathrm{C}$ & $-* *$ & - & & - & $\mathrm{C}$ & $\mathrm{C}$ & $\mathrm{C}$ & & $G$ & $\mathrm{C}$ \\
\hline & & & & & & & & $B T\left(B^{\prime}\right.$ & T1) & & & & & & & & & & & & & & $E F-10$ & & & & & & \\
\hline number & 57 & 96 & 102 & 105 & 127 & 174 & 175 & 176 & 177 & 178 & 179 & 181 & 184 & 191 & 397 & 25 & 37 & 38 & 66 & 118 & 119 & 120 & 128 & 204 & 205 & 220 & 224 & 230 & 239 \\
\hline $\begin{array}{l}\text { C. cerciana } \\
\text { CERC } 9125\end{array}$ & $\mathrm{C}$ & $\mathrm{C}$ & G & G & $T$ & $\mathrm{C}$ & $\mathrm{T}$ & $\mathbf{C}$ & C & C & $\mathrm{C}$ & $\mathrm{C}$ & $\mathrm{C}$ & $A$ & G & $\mathrm{C}$ & $\mathrm{T}$ & $\mathrm{T}$ & A & $\mathrm{T}$ & $\mathrm{T}$ & $C$ & A & - & - & A & $\mathrm{G}$ & $\mathrm{T}$ & $\mathrm{T}$ \\
\hline $\begin{array}{l}\text { C. cerciana } \\
\text { CERC9126 }\end{array}$ & $\mathrm{C}$ & $\mathrm{C}$ & $\mathrm{G}$ & $\mathrm{G}$ & $T$ & $\mathrm{C}$ & $\mathrm{T}$ & $\mathbf{C}$ & C & C & $\mathrm{C}$ & $\mathrm{C}$ & $\mathrm{C}$ & $A$ & G & $\mathrm{C}$ & $\mathrm{T}$ & $\mathrm{T}$ & A & $\mathrm{T}$ & $\mathrm{T}$ & $C$ & A & - & - & A & $\mathrm{G}$ & $\mathrm{T}$ & $\mathrm{T}$ \\
\hline $\begin{array}{l}\text { C. cerciana } \\
\text { CERC9127 }\end{array}$ & $\mathrm{C}$ & $\mathrm{C}$ & G & G & $T$ & $\mathrm{C}$ & $\mathrm{T}$ & C & C & C & $\mathrm{C}$ & $\mathrm{C}$ & $\mathrm{C}$ & $A$ & $\mathrm{G}$ & $\mathrm{C}$ & $\mathrm{T}$ & $\mathrm{T}$ & A & $\mathrm{T}$ & $\mathrm{T}$ & $C$ & A & - & - & A & G & $\mathrm{T}$ & $\mathrm{T}$ \\
\hline $\begin{array}{l}\text { C. cerciana } \\
\text { CERC9128 }\end{array}$ & $\mathrm{C}$ & $\mathrm{C}$ & G & $\mathrm{G}$ & $T$ & $\mathrm{C}$ & $\mathrm{T}$ & C & C & C & $\mathrm{C}$ & $\mathrm{C}$ & $\mathrm{C}$ & $A$ & $\mathrm{G}$ & $\mathrm{C}$ & $\mathrm{T}$ & $\mathrm{T}$ & A & $\mathrm{T}$ & $\mathrm{T}$ & $C$ & A & - & - & A & $\mathrm{G}$ & $\mathrm{T}$ & $\mathrm{T}$ \\
\hline $\begin{array}{l}\text { C. eucalypti } \\
\text { CMW } 26900\end{array}$ & $\mathrm{C}$ & $\mathrm{C}$ & G & $\mathbf{A}$ & $\mathrm{C}$ & $\mathrm{C}$ & $\mathrm{T}$ & - & - & - & $\mathrm{C}$ & $\mathbf{T}$ & $\mathrm{C}$ & $\mathrm{C}$ & G & $\mathbf{T}$ & $G$ & $C$ & A & $\mathrm{T}$ & $\mathrm{T}$ & $\mathrm{T}$ & A & - & - & A & G & $\mathrm{T}$ & $\mathrm{T}$ \\
\hline $\begin{array}{l}\text { C. eucalypti } \\
\text { CMW } 26908\end{array}$ & $\mathrm{C}$ & $\mathrm{C}$ & G & $\mathbf{A}$ & $\mathrm{C}$ & $\mathrm{C}$ & $\mathrm{T}$ & - & - & - & $\mathrm{C}$ & $\mathbf{T}$ & $\mathrm{C}$ & $\mathrm{C}$ & $\mathrm{G}$ & $\mathbf{T}$ & $G$ & $C$ & A & $\mathrm{T}$ & $\mathrm{T}$ & $\mathrm{T}$ & A & - & - & A & G & $\mathrm{T}$ & $\mathrm{T}$ \\
\hline $\begin{array}{l}\text { C. syzygii } \\
\text { CMW } 24912\end{array}$ & $\mathrm{C}$ & $\mathrm{C}$ & G & G & $T$ & $\mathrm{C}$ & $\mathrm{T}$ & - & - & - & -* & $\mathrm{C}$ & $\mathrm{C}$ & $A$ & G & $\mathrm{C}$ & $\mathrm{T}$ & $\mathrm{T}$ & A & $\mathrm{T}$ & $\mathrm{T}$ & $C$ & A & - & - & A & $\mathrm{G}$ & $\mathrm{T}$ & $\mathrm{T}$ \\
\hline $\begin{array}{l}\text { C. syzygii } \\
\text { CMW } 34023\end{array}$ & $\mathrm{C}$ & $\mathrm{C}$ & $\mathrm{G}$ & $\mathrm{G}$ & $T$ & $\mathrm{C}$ & $\mathrm{T}$ & - & - & - & -* & $\mathrm{C}$ & $\mathrm{C}$ & $A$ & $\mathrm{G}$ & $\mathrm{C}$ & $\mathrm{T}$ & $\mathrm{T}$ & A & $\mathrm{T}$ & $\mathrm{T}$ & $C$ & A & - & - & A & $\mathrm{G}$ & $\mathrm{T}$ & $\mathrm{T}$ \\
\hline $\begin{array}{l}\text { C. guangdongensis } \\
\text { CMW 12750 }\end{array}$ & $\mathbf{T}$ & $\mathrm{C}$ & G & $\mathrm{G}$ & $\mathrm{C}$ & $\mathbf{T}$ & $\mathbf{C}$ & - & - & - & -* & $\mathrm{C}$ & $T$ & $\mathrm{C}$ & $\mathrm{G}$ & $\mathrm{C}$ & $G$ & $C$ & A & _* & _* & - & $C$ & $A$ & - & G & $A$ & $\mathbf{C}$ & C \\
\hline $\begin{array}{l}\text { C. indonesiensis } \\
\text { CMW 10781 }\end{array}$ & $\mathrm{C}$ & $\mathbf{G}$ & $\mathbf{A}$ & $\mathrm{G}$ & $\mathrm{C}$ & $\mathrm{C}$ & $\mathrm{T}$ & - & - & - & $\mathrm{C}$ & $\mathrm{C}$ & $T$ & $\mathrm{C}$ & $\mathbf{A}$ & $\mathrm{C}$ & $G$ & $C$ & $\mathbf{G}$ & -* & $-*$ & - & $C$ & $A$ & C & A & $A$ & $\mathrm{~T}$ & $\mathrm{~T}$ \\
\hline
\end{tabular}

a Polymorphic nucleotides occurring only in all isolates are shown, not alleles that partially occur in individuals per phylogenetic group. Numerical positions of the nucleotides in the DNA sequence alignments are indicated. Fixed polymorphisms for each group are in bold or -** and those fixed but shared between two or more groups are in italics or $-*$. N/A represents sequences that are not available.

${ }^{\mathrm{b}}$ Ex-type isolates are indicated in bold. 
on $E$. urophylla $\times E$. grandis clone CEPT53 branch tissue on 4 June 2017, Wen Wang, culture CERC9126 = CGMCC3.18864; and CSFF2042, isolate CERC9127 artificial inoculation on E. grandis $\times$ E. urophylla clone CEPT45 branch tissue on 4 June 2017, Wen Wang, culture CERC9127 = CGMCC3.18865.

Notes. Eight species in the genus Celoporthe have been described, including C. cerciana, $C$. dispersa, C. eucalypti, $C$. fontata, C. guangdongensis, $C$. indonesiensis, $C$. syzygii, and C. woodiana. $C$. cerciana differs morphologically from the other seven species by the presence of conidiomatal necks (Chen et al. 2011; Nakabonge et al. 2006; Vermeulen et al. 2013). For all eight Celoporthe spp., the optimal growth temperature of $C$. cerciana, $C$. dispersa, and $C$. woodiana is $25^{\circ} \mathrm{C}$, whereas the paraphyses or cylindrical sterile cells of $C$. cerciana (up to $88 \mu \mathrm{m}$ ) are longer than that of $C$. woodiana (up to $55 \mu \mathrm{m}$ ) and $C$. dispersa (up to $39 \mu \mathrm{m}$ ) (Chen et al. 2011; Vermeulen et al. 2013). C. cerciana is phylogenetically most closely related to C. eucalypti, C. guangdongensis, $C$. indonesiensis, and $C$. syzygii. The five species could not be readily distinguished based on morphological characteristics; only small differences were observed. The conidia sizes among $C$. cerciana (average $3.6 \times 1.5 \mu \mathrm{m}$ ), C. eucalypti (average $3.5 \times 1.6 \mu \mathrm{m}$ ), and $C$. guangdongensis (average $3.5 \times$ $1.5 \mu \mathrm{m}$ ) are close but bigger than $C$. syzygii (average $3.1 \times$ $1.3 \mu \mathrm{m}$ ) and narrower and wider than $C$. indonesiensis (average $3.9 \times 1.3 \mu \mathrm{m})$. The optimal growth temperature of $C$. cerciana is $25^{\circ} \mathrm{C}$, whereas that of the other four species is $30^{\circ} \mathrm{C}$ (Chen et al. 2011).

Pathogenicity tests. Ten isolates (CERC9125, CERC9126, CERC9217, CERC9128, CERC10420, CERC10422, CERC10428,

Table 4. Nucleotide differences observed in the internal transcribed spacer (ITS) and $\beta$-tubulin (BT2/BT1) gene regions between the isolates of Celoporthe syzygii collected in this study ${ }^{\mathrm{a}}$

\begin{tabular}{|c|c|c|c|c|c|c|c|c|c|c|c|c|c|c|c|c|c|}
\hline \multirow[b]{2}{*}{ Isolate number } & \multirow[b]{2}{*}{ Haplotype ${ }^{b}$} & \multicolumn{7}{|c|}{ ITS } & \multicolumn{5}{|c|}{$B T 2$} & \multicolumn{4}{|c|}{ BT1 } \\
\hline & & 28 & 40 & 136 & 137 & 166 & 248 & 256 & 222 & 223 & 224 & 239 & 380 & 176 & 177 & 178 & 179 \\
\hline CMW $34023^{\mathrm{c}}$ & & N/A & N/A & - & - & A & A & A & A & - & $\mathrm{C}$ & G & G & - & - & - & $\mathrm{C}$ \\
\hline CERC10420 & AA & A & A & - & - & A & A & A & $C$ & - & $\mathrm{C}$ & $C$ & G & $C$ & $C$ & $C$ & $\mathrm{C}$ \\
\hline CERC10418 & $\mathrm{BB}$ & A & A & - & - & $G$ & A & A & $\mathrm{A}$ & - & $\mathrm{C}$ & G & G & - & - & - & $\mathrm{C}$ \\
\hline CERC10419 & $\mathrm{BC}$ & A & A & - & - & $G$ & A & A & -* & - & -* & $C$ & G & - & - & - & $-*$ \\
\hline CERC10428 & $\mathrm{BD}$ & A & A & - & - & $G$ & A & A & -* & - & -* & $C$ & $\mathrm{G}$ & - & - & - & $\mathrm{C}$ \\
\hline CERC10433 & BD & A & A & - & - & $G$ & A & A & -* & - & -* & $C$ & $\mathrm{G}$ & - & - & - & $\mathrm{C}$ \\
\hline CERC10434 & BD & A & A & - & - & $G$ & A & A & -* & - & -* & $C$ & G & - & - & - & $\mathrm{C}$ \\
\hline CERC10449 & $\mathrm{BE}$ & A & A & - & - & $G$ & A & A & A & $C$ & $\mathrm{C}$ & G & G & - & - & - & $\mathrm{C}$ \\
\hline CERC10450 & $\mathrm{BE}$ & A & A & - & - & $G$ & $\mathrm{~A}$ & A & A & $C$ & $\mathrm{C}$ & G & G & - & - & - & $\mathrm{C}$ \\
\hline CERC10451 & $\mathrm{BE}$ & A & A & - & - & $G$ & A & A & A & $C$ & $\mathrm{C}$ & $\mathrm{G}$ & $\mathrm{G}$ & - & - & - & $\mathrm{C}$ \\
\hline CERC10452 & $\mathrm{BE}$ & A & A & - & - & $G$ & A & A & A & $C$ & $\mathrm{C}$ & G & $\mathrm{G}$ & - & - & - & $\mathrm{C}$ \\
\hline CERC10422 & $\mathrm{CF}$ & A & A & - & - & $G$ & $-^{*}$ & A & -* $^{*}$ & - & $-^{*}$ & $C$ & $C$ & - & - & - & $\mathrm{C}$ \\
\hline CERC10423 & $\mathrm{CF}$ & A & A & - & - & $G$ & $-*$ & A & -* & - & $-*$ & $C$ & $C$ & - & - & - & $\mathrm{C}$ \\
\hline CERC10424 & $\mathrm{CF}$ & A & A & - & - & $G$ & $-*$ & A & -* $^{*}$ & - & $-^{*}$ & $C$ & $C$ & - & - & - & $\mathrm{C}$ \\
\hline CERC10425 & $\mathrm{CF}$ & A & A & - & - & $G$ & $-*$ & A & -* $^{*}$ & - & $-^{*}$ & $C$ & $C$ & - & - & - & $\mathrm{C}$ \\
\hline CERC10426 & $\mathrm{CF}$ & A & A & - & - & $G$ & -* & A & -* & - & -* $^{*}$ & $C$ & $C$ & - & - & - & $\mathrm{C}$ \\
\hline CERC10427 & $\mathrm{CF}$ & A & A & - & - & $G$ & -* & A & -* $^{*}$ & - & $-*$ & $C$ & $C$ & - & - & - & $\mathrm{C}$ \\
\hline CERC10429 & $\mathrm{CF}$ & A & A & - & - & $G$ & -* & A & -* & - & -* $^{*}$ & $C$ & $C$ & - & - & - & $\mathrm{C}$ \\
\hline CERC10430 & $\mathrm{CF}$ & A & A & - & - & $G$ & $-*$ & A & -* & - & $-*$ & $C$ & $C$ & - & - & - & $\mathrm{C}$ \\
\hline CERC10453 & CG & A & G & - & - & $G$ & $-*$ & A & -* $^{*}$ & - & $-*$ & $C$ & G & - & - & - & $-*$ \\
\hline CERC10454 & CG & A & G & - & - & $G$ & -* & A & -* & - & _* & $C$ & $\mathrm{G}$ & - & - & - & -* \\
\hline CERC10455 & CG & A & $\mathrm{G}$ & - & - & $G$ & -* & A & -* & - & -* & $C$ & $\mathrm{G}$ & - & - & - & -* \\
\hline CERC10442 & DH & - & A & $C$ & $C$ & A & $-*$ & $T$ & -* $^{*}$ & - & $\mathrm{C}$ & $C$ & $\mathrm{G}$ & - & - & - & $\mathrm{C}$ \\
\hline CERC10443 & DH & - & A & $C$ & $C$ & A & $-*$ & $T$ & -* $^{*}$ & - & $\mathrm{C}$ & $C$ & G & - & - & - & $\mathrm{C}$ \\
\hline CERC10447 & DH & - & A & $C$ & $C$ & A & $-*$ & $T$ & $-*$ & - & $\mathrm{C}$ & $C$ & G & - & - & - & $\mathrm{C}$ \\
\hline CERC10448 & DH & - & A & $C$ & $C$ & A & $-*$ & $T$ & -* $^{*}$ & - & $\mathrm{C}$ & $C$ & $\mathrm{G}$ & - & - & - & $\mathrm{C}$ \\
\hline
\end{tabular}

${ }^{a}$ Nucleotide differences for each isolate are shown and numerical positions of the nucleotides in the DNA sequence alignments are indicated. N/A represents sequences that are not available. Nucleotides different from ex-type isolate are shown in italics or -*.

${ }^{\mathrm{b}}$ Haplotype of each $C$. syzygii isolate obtained in this study, determined by sequences of ITS and BT2/BT1 regions.

${ }^{\mathrm{c}}$ Ex-type isolate of $C$. syzygii.

Table 5. Nucleotide differences observed in the internal transcribed spacer (ITS), two regions of $\beta$-tubulin (BT2/BT1), and translation elongation factor1- $\alpha$ $(T E F-1 \alpha)$ gene regions between the isolate CERC10436 (Celoporthe sp.) and isolates of Celoporthe eucalypti and C. syzygii ${ }^{\text {a }}$

\begin{tabular}{|c|c|c|c|c|c|c|c|c|c|c|c|c|c|c|c|c|c|c|c|c|c|c|c|c|c|c|}
\hline \multirow[b]{2}{*}{ Species, isolate ${ }^{b}$} & \multicolumn{10}{|c|}{ ITS } & \multicolumn{6}{|c|}{$B T(B T 2)$} & \multicolumn{6}{|c|}{$B T(B T 1)$} & \multicolumn{4}{|c|}{$T E F-1 \alpha$} \\
\hline & 92 & 93 & 97 & 100 & 118 & 132 & 180 & 210 & 538 & 540 & 24 & 222 & 223 & 234 & 238 & 322 & 105 & 127 & 176 & 177 & 178 & 188 & 25 & 37 & 38 & 120 \\
\hline $\begin{array}{l}\text { C. eucalypti } \\
\text { CMW } 26900\end{array}$ & $C$ & $T$ & $C$ & $G$ & $-^{*}$ & $G$ & $A$ & $-*$ & $T$ & $T$ & $\mathrm{~T}$ & -* & $C$ & $\mathrm{~T}$ & $C$ & $\mathrm{C}$ & $\mathrm{A}$ & $\mathrm{C}$ & $\mathrm{C}$ & $C$ & $\mathrm{~T}$ & $\mathrm{C}$ & $\mathrm{T}$ & $\mathrm{G}$ & $\mathrm{C}$ & $\bar{T}$ \\
\hline $\begin{array}{l}\text { C. eucalypti } \\
\text { CMW } 26908\end{array}$ & $C$ & $T$ & $C$ & $G$ & $-*$ & $G$ & $A$ & $-*$ & $T$ & $T$ & $\mathrm{~T}$ & $-*$ & $C$ & $\mathrm{~T}$ & $C$ & $\mathrm{C}$ & A & $\mathrm{C}$ & $\mathrm{C}$ & $C$ & $\mathrm{~T}$ & $\mathrm{C}$ & $\mathrm{T}$ & G & $\mathrm{C}$ & $\mathrm{T}$ \\
\hline $\begin{array}{c}\text { Celoporthe sp. } \\
\text { CERC10436 }\end{array}$ & $C$ & $T$ & $C$ & $G$ & $-*$ & $G$ & $A$ & $-*$ & $T$ & $T$ & $C$ & $-*$ & - & $C$ & $C$ & $A$ & $G$ & $T$ & $-*$ & - & $C$ & $A$ & $C$ & $T$ & $T$ & C \\
\hline $\begin{array}{l}\text { C. syzygii } \\
\text { CMW } 24912\end{array}$ & $\mathrm{~T}$ & $\mathrm{C}$ & $\mathrm{T}$ & $\mathrm{C}$ & $\mathrm{C}$ & - & - & A & $\mathrm{C}$ & - & $C$ & A & $C$ & $C$ & $\mathrm{G}$ & $A$ & $G$ & $T$ & $-^{*}$ & $C$ & $C$ & $A$ & $C$ & $T$ & $T$ & $C$ \\
\hline $\begin{array}{l}\text { C. syzygii } \\
\text { CMW } 34023\end{array}$ & $\mathrm{~T}$ & $\mathrm{C}$ & $\mathrm{T}$ & $\mathrm{C}$ & $\mathrm{C}$ & - & - & $\mathrm{A}$ & $\mathrm{C}$ & - & $C$ & A & $C$ & $C$ & $\mathrm{G}$ & $A$ & $G$ & $T$ & -* & $C$ & $C$ & $A$ & $C$ & $T$ & $T$ & $C$ \\
\hline
\end{tabular}

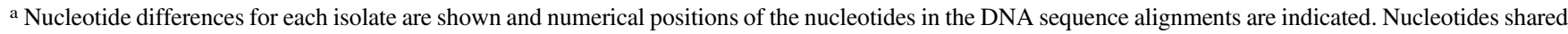
between two species are shown in italics or -*.

${ }^{\mathrm{b}}$ Ex-type isolates are indicated in bold. 
CERC10436, and CERC10449 from Eucalyptus and CERC10453 from $M$. candidum) representing different species of Celoporthe were used for the inoculations. All 10 isolates produced lesions on the three tested Eucalyptus clones, whereas only wounds but no lesions were produced in the control inoculations. The lesions produced by some Celoporthe isolates on some Eucalyptus clones were significantly longer than the wounds on the controls (Fig. 4A). For example, lesions produced by some isolates of C. cerciana (CERC9126 and CERC9127), C. syzygii (CERC10420, CERC10428, and CERC10449), and Celoporthe sp. (CERC10436) on clones CEPT45 and CEPT53 were significantly longer than the controls $(P<0.05)$ (Fig. 4A). The overall data revealed that the three Celoporthe spp. have similar levels of pathogenicity (Fig. 4A). Furthermore, the lesion length produced by the inoculated isolate (CERC10453) derived from M. candidum was similar to that of the nine isolates from Eucalyptus (Fig. 4A). Statistical analyses of the data showed that not all isolates of same Celoporthe spp. reacted in the same manner to the tested $\mathrm{Eu}$ calyptus clones. For example, lesions produced by CERC10420 and CERC10428 on Eucalyptus clone CEPT53 were significantly longer than those of CERC10453 $(P<0.05)$ (Fig. 4A), whereas, for the $E u$ calyptus clones CEPT45 and CEPT46, the lesions produced by the three $C$. syzygii isolates were not significantly different (Fig. 4A). The results also showed that the tolerance of Eucalyptus clones differs significantly for some inoculated isolates; for example, CEPT46 is more tolerant than CEPT53 toward some isolates of $C$. cerciana (CERC9126, CERC9127, and CERC9128) and C. syzygii (CERC10428 and CERC10449). The overall data further showed that CEPT53 is the most susceptible to Celoporthe spp., whereas CEPT46 is relatively tolerant (Fig. 4B). Yellow or orange fruiting structures and cankers were produced on the bark of inoculated trees within 4 weeks; these structures displayed similar morphological characteristics of conidiomata on the Eucalyptus trees in the
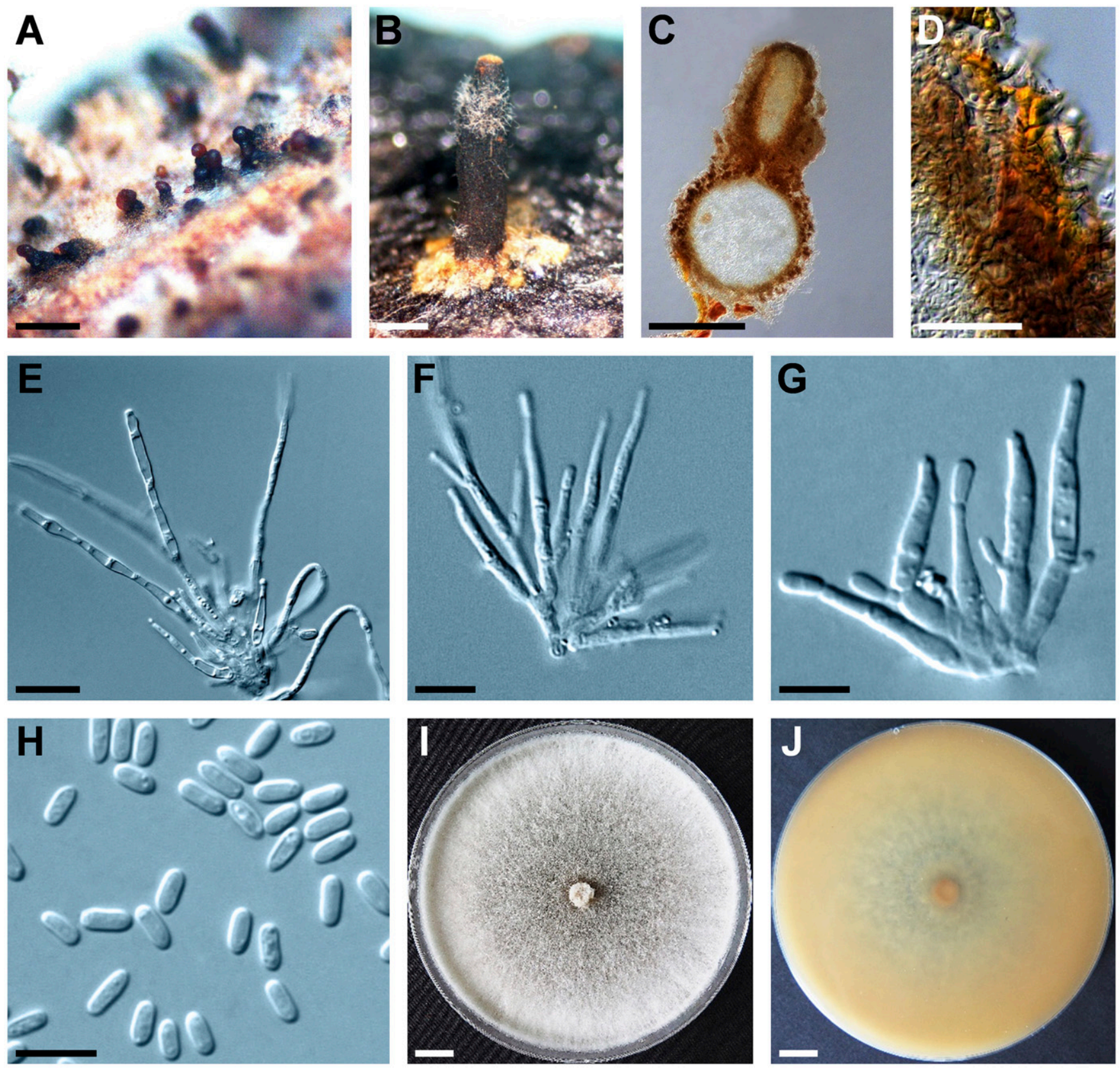

Fig. 3. Asexual fruiting structures of Celoporthe cerciana induced to form on Eucalyptus grandis hybrid branch sections in culture. A, Conidiomata on the bark produced conidial spore mass. B, Conidioma with long black necks. C, Longitudinal section through conidioma showing umber stroma. D, Prosenchymatous stromatic tissue of the conidioma. E, Paraphyses. F and G, Conidiophores and conidiogenous cells. H, Nonseptate, oblong to cylindrical conidia. I, Living culture after growing 10 days on malt extract agar (MEA) (front). $\mathrm{J}$, Living culture after growing 10 days on MEA (reverse). Scale bars: $\mathrm{A}$ to $\mathrm{C}=500 \mu \mathrm{m}, \mathrm{D}=50 \mu \mathrm{m}, \mathrm{E}=10 \mu \mathrm{m}, \mathrm{F}$ to $\mathrm{H}=5 \mu \mathrm{m}$, and I to $\mathrm{J}=10 \mathrm{~mm}$. 
field and the reisolated fungi from lesions share the same culture morphology with the Celoporthe fungi originally from the Eucalyptus trees in the plantation. The inoculated Celoporthe fungi were successfully reisolated from the lesions but not from the control, indicating that the Koch's postulates had been fulfilled.

\section{Discussion}

In this study, a stem disease was observed on 8-year-old E. grandis $\times$ E. urophylla hybrid clones in a plantation in southern China. Fruiting structures with typical morphological characteristics of fungi in the family Cryphonectriaceae were observed on the cankered bark (Gryzenhout et al. 2009). The fungi isolated from the diseased tissues were identified based on phylogenetic analyses and morphological characteristics. These fungi were identified as $C$. syzygii and one previously undescribed species, hereby designated as $C$. cerciana sp. nov. Inoculation tests showed that the Celoporthe spp. identified in this study are pathogenic to the three tested $E$. grandis hybrid clones, which are widely cultivated in southern China.

The Celoporthe spp. isolated from Eucalyptus in this study were all from the cankered bark of living 8-year-old trees. The cankers crack the bark and girdle the stems, thereby killing the cambium. The inoculations in this study consistently showed that all of the Celoporthe spp. isolates produced lesions on the three E. grandis hybrid clones, and made similar disease symptoms on inoculated trees as on the diseased plantation-grown Eucalyptus trees in the field. Previously, species of Celoporthe were isolated from cankered Eucalyptus and the inoculation results supported the idea that they are pathogenic to all the tested Eucalyptus clones (Chen et al. 2011). Results in current and previous studies all support the conclusion that species of Celoporthe are pathogens of Eucalyptus that caused damage on Eucalyptus trees in China.

Eight species of Celoporthe are currently recognized, all of which have been collected from Myrtales trees. Three Celoporthe spp. were first isolated in Africa, including $C$. dispersa that was isolated from native Syzygium cordatum (Myrtaceae, Myrtales), S. legatii, and Heteropyxis canescens (Myrtaceae, Myrtales) (Nakabonge et al. 2006; Vermeulen et al. 2011, 2013); C. fontata from native $S$. guineense in Zambia (Nakabonge et al. 2006; Vermeulen et al. 2011, 2013); and $C$. woodiana from nonnative Tibouchina granulosa (Melastomataceae, Myrtales) in South Africa (Nakabonge et al. 2006; Vermeulen et al. 2011, 2013). The other five Celoporthe spp. were all first isolated from Myrtaceae trees in Asia, including C. indonesiensis isolated from S. aromaticum; C. syzygii from S. cumini; and C. cerciana, C. eucalypti, and C. guangdongensis from Eucalyptus trees. Except for $C$. indonesiensis that was collected in Indonesia, the other four
Celoporthe spp. were all isolated in China. The results in the current study further revealed intraspecific variations in $C$. syzygii. Only a few studies on Celoporthe spp. in China have been conducted (Chen et al. 2011), and studies of the diversity of Celoporthe spp. in China and other regions in Asia are limited. The results in this study suggest that Celoporthe spp. possibly have high genetic diversity in Myrtales trees in China and other regions of Asia.

The family Cryphonectriaceae includes some globally significant pathogens that have been isolated from Myrtales trees (Gryzenhout et al. 2009). Although $C$. syzygii and $C$. cerciana were isolated and identified from Eucalyptus trees in this study, Cryphonectriaceae species are frequently isolated from Myrtales trees in southern China, such as $C$. deuterocubensis isolated from multiple Eucalyptus genotypes in different provinces and S. cumini in GuangDong Province (Chen et al. 2010); the three Celoporthe spp. C. syzygii from $S$. cumini and C. eucalypti and C. guangdongensis from Eucalyptus trees, all isolated in GuangDong Province (Chen et al. 2011); Corticimorbus sinomyrti, isolated from native Rhodomyrtus tomentosa (Myrtaceae, Myrtales) in GuangXi Province and the Hong Kong Region (Chen et al. 2016b); and Chrysomorbus lagerstroemiae, isolated from nonnative Lagerstroemia speciosa (Lythraceae, Myrtales) in the GuangXi and HaiNan Provinces (Chen et al. 2018). Pathogenicity tests showed that all of these Cryphonectriaceae species isolated in southern China were pathogenic to the tested Eucalyptus genotypes (Chen et al. 2010, 2011, 2016a,b, 2018).

Two genera in Cryphonectriaceae (namely, Chrysoporthe and Celoporthe) were isolated from Eucalyptus trees in China, and the resulting disease symptoms were very similar (Chen et al. 2010, 2011). These two genera can be distinguished by conidiomata and conidiomatal neck morphological features, whereas the fruiting structures between Celoporthe spp. are morphologically very similar, which renders identification relatively difficult, particularly when this is mainly based on fruiting structure morphology. Some differences were observed for pathogenicity among different Celoporthe spp. on Eucalyptus. These results suggest that more surveys of disease caused by Cryphonectriaceae should be conducted, and these fungi need to be identified, especially by DNA sequence comparisons, to better understand the geographic distribution and diversity of Cryphonectriaceae spp. on Eucalyptus in China.

Members of the family Cryphonectriaceae appear to be common as natives on species of Myrtales and to have the capacity to easily adapt to infect other Myrtales hosts, including Eucalyptus trees (Burgess and Wingfield 2017; Heath et al. 2006; van der Merwe et al. 2013; Vermeulen et al. 2011, 2013). In this study, in addition to the Eucalyptus trees, C. syzygii was also isolated from native $M$. candidum in the same
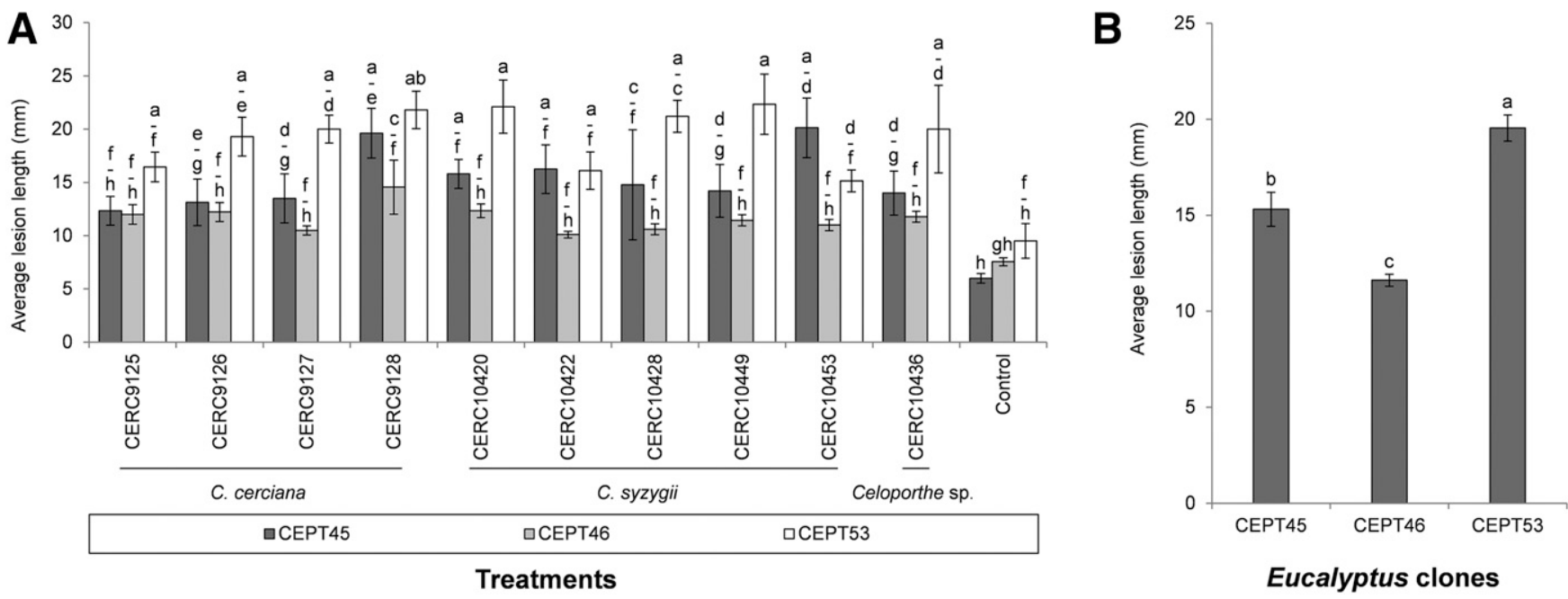

Fig. 4. A, Column chart indicating the average lesion length (in millimeters) produced by each isolate of Celoporthe spp. on three Eucalyptus hybrids. Bars topped with different letters indicate treatment means that are significantly different $(P=0.05)$. B, Column chart indicating the average lesion length (in millimeters) on three Eucalyptus hybrids after inoculation with a mycelium plug of Celoporthe spp. Bars topped with different letters indicate significant differences among clones $(P=0.05)$. 
Eucalyptus plantation; the inoculations showed that it was pathogenic to the three tested Eucalyptus clones. Furthermore, C. syzygii was also isolated from S. cumini trees in China (Chen et al. 2011). These results indicate that $C$. syzygii might have a wide geographic and host distribution. In this study, Celoporthe spp. cause debilitating cankers on Eucalyptus trees. This is similar to the situation in South America and Africa, where C. cubensis and C. austroafricana from native Tibouchina or Syzygium spp., respectively, have adapted to become a severe pathogen of plantation-grown Eucalyptus (Gryzenhout et al. 2009; Heath et al. 2006; Rodas et al. 2005).

Previous studies indicated that phylogenetic analyses can identify hybrids as intermediate clades with incongruent phylogenetic topologies (Cruywagen et al. 2017; Schardl and Craven 2003). Phylogenetic analyses in this study showed that one isolate (CERC10436) was grouped incongruently in trees generated from three different gene regions. This has also been found in studies of other plant pathogen species where hybridization has been indicated between different species (Cruywagen et al. 2017; O'Donnell et al. 2000). The results in this study suggest that hybridization may occur between C. eucalypti and $C$. syzygii and, thus, further studies to confirm the occurrence of hybridization and clarify its influence on evolution of Celoporthe spp. are necessary.

The plantation from which C. eucalypti was first isolated by Chen et al. (2011) is the same one from which $C$. cerciana and $C$. syzygii were collected in this study. Currently, multiple species of Celoporthe were isolated from the diseased materials. Isolate CERC10436, which might be a hybrid between $C$. eucalypti and $C$. syzygii, and isolates of $C$. syzygii were isolated from the same Eucalyptus bark. Inoculation results showed that all of the tested isolates of different Celoporthe spp. produced similar-sized lesions on Eucalyptus trees. These results suggest that the disease on Eucalyptus in this study might have resulted from the interaction of different Celoporthe spp.

The results of this study expand our understanding of the host range, geographic distribution, genetic diversity, and pathogenicity of Celoporthe spp. Industrial Eucalyptus plantations in China are typically single species or hybrid plantings, often from a few clones that share a common parentage (Turnbull 2007; Wei 2005; Zhou and Wingfield 2011). The model of large-scale plantations with few clones greatly increases the threat from pests and diseases (Wingfield 2003; Wingfield et al. 2008). In recent years, the sustainable development of Eucalyptus plantations in China has been increasingly threatened by pathogens (Zhou and Wingfield 2011). The results of pathogenicity testing may provide information on the selection of commercially available Eucalyptus clones that are tolerant to Celoporthe pathogens to control and manage the pathogen in China.

\section{Acknowledgments}

We thank LetPub (www.LetPub.com) for providing linguistic assistance during the preparation of this article.

\section{Literature Cited}

Anagnostakis, S. L. 1987. Chestnut blight: The classical problem of an introduced pathogen. Mycologia 79:23-37.

Burgess, T. I., and Wingfield, M. J. 2017. Pathogens on the move: A 100-year global experiment with planted eucalypts. Bioscience 67:14-25.

Cao, J. D. 1982. Investigation of bacterial wilt in Eucalyptus saligna and E. grandis introduced from Brazil. Guangxi For. Sci. Technol. 4:30-31. (In Chinese).

Chen, S. F., Gryzenhout, M., Roux, J., Xie, Y. J., Wingfield, M. J., and Zhou, X. D. 2010. Identification and pathogenicity of Chrysoporthe cubensis on Eucalyptus and Syzygium spp. in South China. Plant Dis. 94:1143-1150.

Chen, S. F., Liu, Q. L., Li, G. Q., and Wingfield, M. J. 2017. Quambalaria species associated with Eucalypt diseases in southern China. Front. Agric. Sci. Eng. 4: 433-447.

Chen, S. F., Liu, Q. L., Li, G. Q., Wingfield, M. J., and Roux, J. 2018. A new genus of Cryphonectriaceae isolated from Lagerstroemia speciosa in Southern China. Plant Pathol. 67:107-123.

Chen, S. F., Lombard, L., Roux, J., Xie, Y. J., Wingfield, M. J., and Zhou, X. D. 2011. Novel species of Celoporthe from Eucalyptus and Syzygium trees in China and Indonesia. Mycologia 103:1384-1410.

Chen, S. F., van der Merwe, N. A., Wingfield, M. J., and Roux, J. 2016a. Population structure of Holocryphia capensis (Cryphonectriaceae) from
Metrosideros angustifolia and its pathogenicity to Eucalyptus species. Australas. Plant Pathol. 45:201-207.

Chen, S. F., Wingfield, M. J., Li, G. Q., and Liu, F. F. 2016b. Corticimorbus sinomyrti gen. et sp. nov. (Cryphonectriaceae) pathogenic to native Rhodomyrtus tomentosa (Myrtaceae) in South China. Plant Pathol. 65:1254-1266.

Chen, S. F., Wingfield, M. J., and Roux, J. 2013. Diversimorbus metrosiderotis, gen. et sp. nov. and three new species of Holocryphia (Cryphonectriaceae) associated with cankers on native Metrosideros angustifolia trees in South Africa. Fungal Biol. 117:289-310.

Cruywagen, E. M., Slippers, B., Roux, J., and Wingfield, M. J. 2017. Phylogenetic species recognition and hybridization in Lasiodiplodia: A case study on species from baobabs. Fungal Biol. 121:420-436.

Gryzenhout, M., Myburg, H., Rodas, C. A., Wingfield, B. D., and Wingfield, M. J. 2006. Aurapex penicillata gen. sp. nov. from native Miconia theaezans and Tibouchina spp. in Colombia. Mycologia 98:105-115.

Gryzenhout, M., Myburg, H., van der Merwe, N. A., Wingfield, B. D., and Wingfield, M. J. 2004. Chrysoporthe, a new genus to accommodate Cryphonectria cubensis. Stud. Mycol. 50:119-141.

Gryzenhout, M., Myburg, H., Wingfield, B. D., Montenegro, F., and Wingfield, M. J. 2005. Chrysoporthe doradensis sp. nov. pathogenic to Eucalyptus in Ecuador. Fungal Divers. 20:39-57.

Gryzenhout, M., Tarigan, M., Clegg, P. A., and Wingfield, M. J. 2010. Cryptometrion aestuescens, gen. sp. nov. (Cryphonectriaceae) pathogenic to Eucalyptus in Indonesia. Australas. Plant Pathol. 39:161-169.

Gryzenhout, M., Wingfield, B. D., and Wingfield, M. J. 2009. Taxonomy, Phylogeny, and Ecology of Bark-Inhabiting and Tree Pathogenic Fungi in the Cryphonectriaceae. American Phytopathological Society, St. Paul, MN.

Guindon, S., Dufayard, J. F., Lefort, V., Anisimova, M., Hordijk, W., and Gascuel, O. 2010. New algorithms and methods to estimate maximum-likelihood phylogenies: Assessing the performance of PhyML 3.0. Syst. Biol. 59:307-321.

Heath, R. N., Gryzenhout, M., Roux, J., and Wingfield, M. J. 2006. Discovery of the canker pathogen Chrysoporthe austroafricana on native Syzygium spp. in South Africa. Plant Dis. 90:433-438.

Hillis, D. M., and Huelsenbeck, J. P. 1992. Signal, noise, and reliability in molecular phylogenetic analyses. J. Hered. 83:189-195.

Iglesias-Trabad, G., Carbaeira-Tenreiro, R., and Folgueiia-Lozano, J. 2009. Eucalyptus universalis. Global Cultivated Eucalypt Forest Map, version 1.2. Online publication. GIT Forestry Consulting's EUCALYPTOLOGICS: Information Resources on Eucalyptus Cultivation Worldwide. http://gitforestry-blog.blogspot.com/2008/09/eucalyptus-global-map-2008-cultivated. html

Katoh, K., and Standley, D. M. 2013. MAFFT multiple sequence alignment software version 7: Improvements in performance and usability. Mol. Biol. Evol. 30:772-780.

Li, G. Q., Liu, F. F., Li, J. Q., Liu, Q. L., and Chen, S. F. 2018. Botryosphaeriaceae from Eucalyptus plantations and adjacent plants in China. Persoonia 40:63-95.

Li, J. Q., Wingfield, M. J., Liu, Q. L., Barnes, I., Roux, J., Lombard, L., Crous, P. W., and Chen, S. F. 2017. Calonetria species isolated from Eucalyptus plantations and nurseries in south China. IMA Fungus 8:259-294.

Lombard, L., Chen, S. F., Mou, X., Zhou, X. D., Crous, P. W., and Wingfield, M. J. 2015. New species, hyper-diversity and potential importance of Calonectria spp. from Eucalyptus in South China. Stud. Mycol. 80:151-188.

Myburg, H., Gryzenhout, M., Wingfield, B. D., and Wingfield, M. J. 2003. Conspecificity of Endothia eugeniae and Cryphonectria cubensis: A re-evaluation based on morphology and DNA sequence data. Mycoscience 44:187-196.

Nakabonge, G., Marieka, G., Jolanda, R., Wingfield, B. D., and Wingfield, M. J. 2006. Celoporthe dispersa gen. et sp. nov. from native Myrtales in South Africa. Stud. Mycol. 55:255-267.

O'Donnell, K., Kistler, H. C., Tacke, B. K., and Casper, H. H. 2000. Gene genealogies reveal global phylogeographic structure and reproductive isolation among lineages of Fusarium graminearum, the fungus causing wheat scab. Proc. Natl. Acad. Sci. USA 97:7905-7910.

Old, K. M., Wingfield, M. J., and Yuan, Z. Q. 2003. A Manual of Diseases of Eucalypts in South-East Asia. Centre for International Forestry Research, Jakarta, Indonesia.

Posada, D. 2008. jModelTest: Phylogenetic model averaging. Mol. Biol. Evol. 25: 1253-1256.

Rayner, R. W. 1970. A Mycological Colour Chart. Commonwealth Mycological Institute and British Mycological Society, Kew, UK.

Rodas, C. A., Gryzenhout, M., Myburg, H., Wingfield, B. D., and Wingfield, M. J. 2005. Discovery of the Eucalyptus canker pathogen Chrysoporthe cubensis on native Miconia (Melastomataceae) in Colombia. Plant Pathol. 54:460-470.

Schardl, C. L., and Craven, K. D. 2003. Interspecific hybridization in plantassociated fungi and oomycetes: A review. Mol. Ecol. 12:2861-2873.

SPSS. 2011. IBM SPSS Statistics Base 20. IBM Corporation, Armonk, NY.

Swofford, D. L. 2003. PAUP*. Phylogenetic Analysis Using Parsimony (*and other methods). Version 4.0. Sinauer Associates, Sunderland, MA.

Tamura, K., Stecher, G., Peterson, D., Filipski, A., and Kumar, S. 2013. MEGA6: Molecular evolutionary genetics analysis version 6.0. Mol. Biol. Evol. 30: 2725-2729.

Turnbull, J. W. 2007. Development of Sustainable Forestry Plantations in China: A Review. ACIAR Impact Assessment Ser. Rep. No. 45. Australian Centre for International Agricultural Research, Canberra, ACT Australia. 
van Burik, J. A., Schreckhise, R. W., White, T. C., Bowden, R. A., and Myerson, D. 1998. Comparison of six extraction techniques for isolation of DNA from filamentous fungi. Med. Mycol. 36:299-303.

van der Merwe, N. A., Gryzenhout, M., Steenkamp, E. T., Wingfield, B. D., and Wingfield, M. J. 2010. Multigene phylogenetic and population differentiation data confirm the existence of a cryptic species within Chrysoporthe cubensis. Fungal Biol. 114:966-979.

van der Merwe, N. A., Steenkamp, E. T., Rodas, C., Wingfield, B. D., and Wingfield, M. J. 2013. Host switching between native and non-native trees in a population of the canker pathogen Chrysoporthe cubensis from Colombia. Plant Pathol. 62:642-648.

Vermeulen, M., Gryzenhout, M., Wingfield, M. J., and Roux, J. 2011. New records of the Cryphonectriaceae from Southern Africa including Latruncellus aurorae gen. sp. nov. Mycologia 103:554-569.

Vermeulen, M., Gryzenhout, M., Wingfield, M. J., and Roux, J. 2013. Species delineation in the tree pathogen genus Celoporthe (Cryphonectriaceae) in southern Africa. Mycologia 105:297-311.
Wei, R. P. 2005. Genetic diversity and sustainable productivity of Eucalyptus plantations in China. Pages 19-27 in: Changing Patterns: Tree Introduction and Phytogeography. H. Wang, ed. China Forestry Publishing House, Beijing, China. (In Chinese)

Wingfield, M. J. 2003. 2003 Daniel McAlpine Memorial Lecture. Increasing threat of diseases to exotic plantation forests in the Southern hemisphere: Lessons from Cryphonectria canker. Australas. Plant Pathol. 32:133-139.

Wingfield, M. J., Brockerhoff, E. G., Wingfield, B. D., and Slippers, B 2015. Planted forest health: The need for a global strategy. Science 349: 832-836.

Wingfield, M. J., Slippers, B., and Hurley, B. P. 2008. Eucalypt pests and diseases: Growing threats to plantation productivity. South. For. 70:139-144.

Xie, Y. J., Arnold, R. J., Wu, Z. H., Chen, S. F., Du, A P., and Luo, J. Z. 2017. Advances in eucalypt research in China. Front. Agric. Sci. Eng. 4: 380-390.

Zhou, X. D., and Wingfield, M. J. 2011. Eucalypt diseases and their management in China. Australas. Plant Pathol. 40:339-345. 